\title{
WestVirginiaUniversity
}

THE RESEARCH REPOSITORY @ WVU

Graduate Theses, Dissertations, and Problem Reports

2020

\section{Family Forest Owners Satisfaction with Timber Transactions}

Jeffrey M. Lee

West Virginia University, jlee20@mix.wvu.edu

Follow this and additional works at: https://researchrepository.wvu.edu/etd

Part of the Environmental Studies Commons, Natural Resource Economics Commons, Natural

Resources Management and Policy Commons, and the Other Environmental Sciences Commons

\section{Recommended Citation}

Lee, Jeffrey M., "Family Forest Owners Satisfaction with Timber Transactions" (2020). Graduate Theses, Dissertations, and Problem Reports. 7689.

https://researchrepository.wvu.edu/etd/7689

This Thesis is protected by copyright and/or related rights. It has been brought to you by the The Research Repository @ WVU with permission from the rights-holder(s). You are free to use this Thesis in any way that is permitted by the copyright and related rights legislation that applies to your use. For other uses you must obtain permission from the rights-holder(s) directly, unless additional rights are indicated by a Creative Commons license in the record and/ or on the work itself. This Thesis has been accepted for inclusion in WVU Graduate Theses, Dissertations, and Problem Reports collection by an authorized administrator of The Research Repository @ WVU. For more information, please contact researchrepository@mail.wvu.edu. 


\title{
Family Forest Owners Satisfaction with Timber Transactions
}

\author{
Jeffrey M. Lee
}

\author{
Thesis submitted to the \\ Davis College of Agriculture, Natural Resources, and Design \\ at West Virginia University \\ In partial fulfillment of the requirements for the degree of \\ Masters of Science in Forestry \\ David W. McGill, Ph.D., Chair \\ Joseph McNeel, Ph.D. \\ Kathryn Arano Gazal, Ph. D. \\ Department of Forest Resources Management
}

Morgantown, West Virginia 2020

Keywords: timber transaction, satisfaction, Family Forest Owner

Copyright 2020 Jeffrey M. Lee 


\section{Abstract \\ Family Forest Owners Satisfaction with Timber Transactions}

\section{Jeff Lee}

Forest industries in the eastern U.S. rely heavily on family forest owners to supply fiber needs for their mills. As of 2017, 79 percent of West Virginia is classified as forestland and of this roughly 86.5 percent is privately owned. With such a heavy reliance on wood from private forest lands, family forest owner satisfaction is extremely important if companies want to continue harvesting or working with these landowners in the future.

Timber transactions are complex. No two timber transactions are exactly the same. They often involve many different parties apart from the landowner. Site conditions, land cover, and landowner goals all are major factors that influence the outcome of a timber harvest. A timber harvest can leave a property completely transformed. For better or worse the property will not be the same as before the harvest. Timber harvests are common in West Virginia many lack the use of a forester. Without a forester, landowners are likely at a competitive disadvantage when negotiating timber contracts and accomplishing their goals and future of their properties.

The goal of this study was to explore ways to alleviate common pitfalls that lead to legal or financial issues that are associated with timber transactions. We carried out a mail-based survey to landowners who had recently harvested timber from their West Virginia properties. In this paper, we explore the relationships between landowner satisfaction with a harvest, their property attributes, management goals, and the types of professional assistance they received during their timber transaction.

Many attributes selected to represent conditions and events during timber transactions were found to be significantly related to the overall satisfaction of landowners following timbering operations. The adequacy of several of the attributes were used as indicators of landowners' perception of service quality. Having a forestry professional assist with the timber sale enhanced the likelihood that landowners would be satisfied with timbering outcomes. 


\section{Acknowledgements}

I would like to thank my advisor and committee chair Dr. David McGill for his patience, guidance and daily encouragement. Throughout this project your daily encouragement and has been immeasurable to helping complete this project.

Thanks to my committee members Dr. Joseph McNeel and Dr. Kathryn Gazal for the patience and support they have shown throughout this project. I would like to thank Dr. McNeel again for convincing me to apply to the forestry program.

I would also like to thank my Mom and sister for the encouragement and for checking on my side of the farm since I have been gone. Without my fraternity advisor William "Stitch" Wilson, the idea of graduate school would never have crossed my mind and I thank you for the suggestion. Finally, I would like to thank my late father, because without our long walks in the woods I would not have had an interest in forestry or a love of nature.

Lastly, I would also like to thank all of the participants that were involved in this study. Without your input this research could not have been accomplished. 


\section{Table of Contents}

$\begin{array}{lr}\text { Abstract } & \text { i } \\ \text { Acknowledgements } & \text { ii } \\ \text { List of Figures } & \text { iv } \\ \text { List of Tables } & \text { v }\end{array}$

Chapter 1: Introduction 1

Chapter 2: Literature Review

Private Landowners 4

FFO Goals $\quad 6$

Decision to Sell

The timber sale $\quad 8$

Satisfaction $\quad 11$

Purpose 11

Chapter 3: Methods

FFO selection process $\quad 13$

$\begin{array}{ll}\text { Data Collection } & 14\end{array}$

Deployment $\quad 17$

$\begin{array}{lr}\text { Coding Process } & 18\end{array}$

Importance Performance Analysis $\quad 18$

Gap Analysis $\quad 20$

Variable reduction $\quad 21$

Variable Reduction Results 22

Univariate logistic regression $\quad 24$

Adequacy Index $\quad 25$

Modeling satisfaction $\quad 25$

Chapter 4: Results

Demographics $\quad 27$

Gap Analysis $\quad 29$

Importance-performance analysis $\quad 31$

Univariate logistic regression $\quad 35$

Factors affecting satisfaction 36

Chapter 5: Discussion $\quad 38$

Literature Cited $\quad 42$

Appendix A Name and Definition of Variables used. 48

Appendix B Questionnaire Cover Letter. $\quad 54$

Appendix C Survey Instrument $\quad 55$ 


\section{List of Figures:}

Figure 1. Four party Scenario Timber Transaction Process. Figure Courtesy of David 9 McGill, West Virginia University Extension Service.

Figure 2. Importance-Performance Analysis grid (adapted Martilla et al 1977 and Oh 19 2000).

Figure 3. Importance-Performance Analysis grid (adapted from Abalo et al 2007) 20

Figure 4. Parallel analysis with Eigen values generated from attributes of 24 Management knowledge

Figure 5. Importance-Performance Analysis of Parties involved 31

Figure 6. Importance-Performance Analysis of Planning the harvest 32

Figure 7. Importance-Performance Analysis of Communication 33

Figure 8. Importance-Performance Analysis of Operations 34 


\section{List of Tables}

Table 1. Dependent response variable satisfaction descriptions 15

Table 2. Explanatory and response variable descriptions 16

Table 3. Details of "Knew and Discuss" attribute list from Question 12 of the survey 23

Table 4. Factor Structure for PCA related to variables Discuss and Knew 24

Table 5. FFO Demographic Characteristics by number (n) and proportion (\%) of 28 respondents.

Table 6. Evaluation of performance $(\mathrm{P})$ and importance $(\mathrm{I})$ for parties involved in timber $\quad 30$ sales.

Table 7. Univariate logistic regression of reduced explanatory variables with overall 36 level of satisfaction of timber sale.

Table 8. Logistic regression of two covariates on landowner's overall satisfaction 37

Table 9. Univariate analysis for variables involved in Best Subsets regression 37 


\section{Chapter I: Introduction}

Timber harvesting is a fundamental part of most wood supply chains. Wood processing companies rely on a continuous supply of timber from diverse sources. One of the largest sources of timber comes from family forest owners (FFO). FFOs are considered families, individuals, trusts, estates, family partnerships and other unincorporated groups or individuals that own at least an acre of woodland or forestland (Butler 2004, Butler 2008). In 2002, more than $60 \%$ of timber harvests nationwide were performed on FFO lands while only $3 \%$ of harvests were from national forest lands, representing an all-time low (Adams et al. 2006).

FFOs face important land management decisions that have long-term impacts on their property. Some of these decisions include whether to harvest timber, lease their property, or sell part or all of their property for added income (Ma et al. 2011). To complicate matters, when an FFO decides to harvest timber other parties become involved in the future conditions of the property. The timber sale may include loggers, consulting foresters, procurement foresters, state foresters, and others. All of these parties have a role to play in the success of the sale and future of the land (Rickenbach 2018, Hoover et al. 2002, Bowers et al. 2007, Grotta 2014).

While not a primary objective for owning timberland (Butler et al. 2016), selling timber for harvest can happen suddenly and oftentimes is full of difficult decisions and situations that FFOs need to respond to (Butler et al. 2011, Ma et al. 2011, Kendra et al. 2005). As in any type of transaction, participants want to be satisfied and want to have their expectations met (Hernandez-Espallardo 2011). But satisfaction itself is complex because a consumer can be satisfied with the service that was given but the quality of work can still be poor (Parasuraman et al. 1988). For agencies and organizations that advise landowners on how to sell timber, 
understanding the complexity timber transactions is important because FFOs do not always grasp these intricacies.

Research on FFO's characteristics and behavior ranges from management activities (e.g. Howel et al. 2010, Greene et al. 2006, Joshi et al. 2009, Ma et al. 2011), outreach program participation (Korhonen et al. 2012, Butler et al. 2011, Davis et al. 2015, Butler 2014, Best 2001), harvesting behavior (Zhang et al. 2001, McGill et al. 2006, Favada et al. 2007), and demographics (e.g. Mehmood et al 2005, Sauliner et al. 2017, Walkingstick et al. 2001). However, there has been very little research of FFO's satisfaction with their overall timber sale. Differences such as who and what are involved, species composition, payment method, and even the lay of the land itself all contribute to how complex a timber sale can be for an FFO (McGill et al. 2006, Heiligmann et al. 1986, Grotta 2014, Grushecky et al. 2012, Bower et al. 2007). All of these variables can have an impact on how satisfied an FFO is with their timber sale. Whether an FFO hires a forester, has knowledge of the harvest, or trusts the associated parties involved in the timber sale can have either a positive or negative impact on their experience (Heiligmann et al. 1986, Bowers et al. 2007, Moss et al. 2013, Grotta 2014 Rickenbach 2018). FFOs who used a contract and were aware of the steps involved in completing a timber harvest were found to have a positive experience when selling timber (Maltempie 2017).

Despite the fact that there is little research on FFO satisfaction, university extension programs have tried to educate FFOs about forest management since the Clarke-McNary Act of 1924 (Barden et al. 1996). The act was meant to strengthen forestry extension in the United States to help FFOs plan and implement timber management activities. Yet even with this with 
this effort over the years, more than half of the FFOs of West Virginia who harvested in 20002001, did so without the help of a professional forester (McGill 2006).

In order to add to our understanding of FFO satisfaction with their timber transactions, a questionnaire was designed to investigate recent timber sales in West Virginia. The primary research concern was to determine how overall FFO satisfaction is influenced by events and conditions that occur during a timber transaction. Specifically, research questions included:

Q1. What attributes of a timber sale are indicators of overall FFO satisfaction with their timber sale?

Q2. How important are these attributes to an FFO and how well they are being performed during a timber sale? 


\section{Private Landowners}

\section{Chapter II: Literature Review}

American private forest owners have existed and have made management decisions for their properties even before the Revolutionary War. The newly formed United States federal government distributed land to veterans or families through the Homestead Act of 1862 (12 Stat. 392) to settle the land gained from the Louisiana Purchase of 1803 and lands ceded to the United States at the conclusion of the Mexican American War in 1846. In a way, the Louisiana purchase and private land ownership set the stage for the further growth of the United States (Joy 2003).

Between 1781 to 1940 the United States federal government transferred land to individuals to encourage settlement of the western United States (Poschman 2014). Currently $69 \%$ of western forestland is publicly owned and $31 \%$ is privately owned. Public landowners include federal, state and local governmental agencies (Butler 2016). In contrast, private landowners control up to $81 \%$ of the forestland in the eastern US (Nelson et al. 2010). Private forest ownership makes up the greatest proportion of ownership types in the eastern United States. Changing polices for public lands has caused a shift from harvesting predominantly public lands in the western half of the United States to almost exclusively harvesting the private lands of the eastern United States (Oswalt et al. 2014).

Private landowners are individuals, organizations or corporations who own land. This includes private individuals, business corporations, tribal nations, and other nongovernmental conservation or natural resource organizations (Butler 2016). Private landownership is usually categorized as either industrial or non-industrial. Industrial private landowners own the mills to process timber growing on their property whereas non-industrial forest ownership includes 
anyone or any corporation that does not rely upon the processing of the forest materials for their main income source (Bliss 2010).

Non-industrial private forest owners include family forest owners (FFOs). Approximately 10.7 million FFOs possess roughly 290 million acres of forest or $36 \%$ of all forest land in the United States (Butler et al. 2016). FFOs include families, individuals, trusts, estates, family partnerships and other unincorporated groups or individuals that own forest land (Butler 2008). To be considered an FFO, one must own at least one acre of land that is at least $10 \%$ stocked with trees (Butler et al. 2004). FFOs may have received their forests through inheritance, direct purchase, or by possessing abandoned or overgrown agricultural land (Zhang et al. 2005).

FFOs have increased 11\% from 1990 to 2000 (Zhang et al. 2005). These numbers may be increasing as a result of parcelization. Parcelization is breaking up large tracts of land and selling them as smaller fragments (Mehmood et al. 2001). This increase in FFO numbers was mostly in smaller acreage properties, specifically owners who owned less than 50 acres (Zhang et al. 2005). It is in the interest of government agencies, university extension programs, and even forestry professionals to understand landowner goals for their woodlands. Working with FFOs is important because collectively they affect local and regional economic health (Bengston et al. 2010)

More than half of the timberland in West Virginia — the focal area for this studyis owned by private individuals. Families and individuals own $52 \%$, corporations own $34 \%$ and other private entities own $1 \%$. Only $14 \%$ of the forestland in West Virginia is owned by public entities. The US Forest Service manages 9\%, the state of West Virginia owns 3\% and other public entities own 2\% of forestland (Morin et al. 2017). 


\section{FFO goals}

FFOs are strongly attached and have a strong desire to "do right" by their land and view their properties as a reflection of their lifestyle instead of a means for financial gain (Greene et al. 2006). Three-fourths of Virginia FFOs purchased forest land to "preserve nature" instead of uses for financial gain such as harvesting timber (Kendra and Hull 2005). When forestry professionals are called upon, landowners are frequently asking for help with other goals such as increasing amenity values for their property instead of timber harvesting (Butler et al. 2016).

FFOs commonly own their property for aesthetic and recreation values (Butler et al. 2011) and are not opposed to performing management (Snyder 2018). Studies of South Carolina's FFO's perceptions on chemical methods for controlling privet find that owners who participate in extension or other stewardship programs are likely to have different views and preconceptions about treatments (Howle et al. 2010). Silvicultural activities and property management in West Virginia were found to be commonly performed activities (Joshi et al. 2009). Fifty-nine percent of West Virginia FFOs have performed some sort of management activities on their land (Joshi et al. 2009). FFO concerns may affect how they maintain and use their property.

Understanding FFO behavior can be problematic. Not all FFOs speak or understand the technical jargon or management activities that forestry professionals are accustomed too. Nonparticipating landowners have been described as under-involved in managing their lands but, when resurveyed by phone some owner's responses differ from written surveys and show that 
they do manage their property but are unfamiliar with the jargon used by professionals (Davis et al. 2010).

\section{Decision to Sell}

FFOs sell timber for a variety of reasons such as emergency needs, change of land use, or even to fulfill management goals (Ma et al. 2011). Some FFO attributes have been associated with a predisposition to harvesting timber or managing property such as; how the property was obtained, interests, employment, tenure of ownership, land size, age, and even gender (Joshi et al. 2009, Sauliner et al. 2017). Studies have shown that education has a positive correlation with willingness to harvest (Sauliner et al. 2017). Employment such as being a farmer affects willingness to harvest. This may be due to the farmer's ability to access resources such as stewardship programs or extension agents and their familiarity with equipment that is needed to manage their stands (Joshi et al. 2009).

FFO studies in West Virginia have determined that income is a common reason to harvest. Other reasons to harvest included the stand needed to be thinned, timber was considered mature, or harvesting was part of a management plan (McGill et al. 2006). Amount of owned acreage may also be part of the decision to harvest. FFOs in Virginia who owned larger tracts of were more likely to harvest timber than those with smaller tracts, possibly because a harvested area gets lost in larger tract of land (Sauliner et al. 2017). However, items such as tract size, distance, and timber quality are all part of a logging company's decision to bid or harvest timber (Kittredege et al. 1996). These factors can influence what companies bid on the harvest.

More than half (64.3\%) of FFOs in Virginia have not had assistance of any kind from forestry professionals (Sauliner et al. 2017). Similarly, in West Virginia roughly half of FFOs 
who harvested between 2000-2001 did not have any assistance from a professional forester (McGill et al. 2006). Wetzel county West Virginia FFO's demonstrate their largest landowner concern was damage to their property, followed by items such as loss of control of their land, liens against the property, or being cheated when creating a long-term timber contract (McGill 2008). FFOs in Indiana are interested in performing a harvest but choose not to due to concerns of how trustworthy a logger could be (Ruseva et al. 2014). Data like this helps support the idea FFOs harbor trust issues with industry professionals.

\section{The timber sale}

The reality for many West Virginia FFOs is that they are at a disadvantage when negotiating the sale of their timber. These landowners may not only under value their timber but may also cause changes to their timber stands (McGill et al. 2006). Timber is usually sold either as stumpage or by logs (Bowers et al. 2007). Which means that there will be removal of materials from the FFO's property and it will cause noticeable changes that the landowner will have to accept. Negative economic conditions, poor trees, low value species can add to the difficulty or frustration of finding a logging company (Moss et al. 2013).

Figure 1 explains the complexity of a timber harvest in West Virginia through a fourparty timber transaction that includes a professional forester, logging company, the West Virginia Division of Forestry (WVDOF), Logger and finally the FFO. The first phase is conceptualization where a catalyst causes the FFO to decide to sell timber. The next phase is timber sale preparation where contact is made with a professional forester or in a 3 a party scenario the logger. The forester will help the FFO plan and start the sale by writing up a contract, determining boundaries, and performing a prospectus. The next phase is the timber 
harvesting stage. The logger notifies the West Virginia Department of Forestry (WVDOF) of a harvest that is to be performed and the WVDOF sends a state forester.

The WVDOF is involved in the harvest due to requirements associated with the Logging Sediment Control Act (LSCA). The LSCA was passed by the West Virginia Legislature in 1992 in response to section 208 of the Federal Water Pollution Control Act of 1972 (Spong 2013). The Federal Water Control Act of 1972 requires regulatory agencies such as the WVDOF to regulate locations that have an impact on water quality (U.S. Environmental Protection Agency 1972). All of these parties may or may not exist as a part of a sale and can have an impact on how the sale concludes.

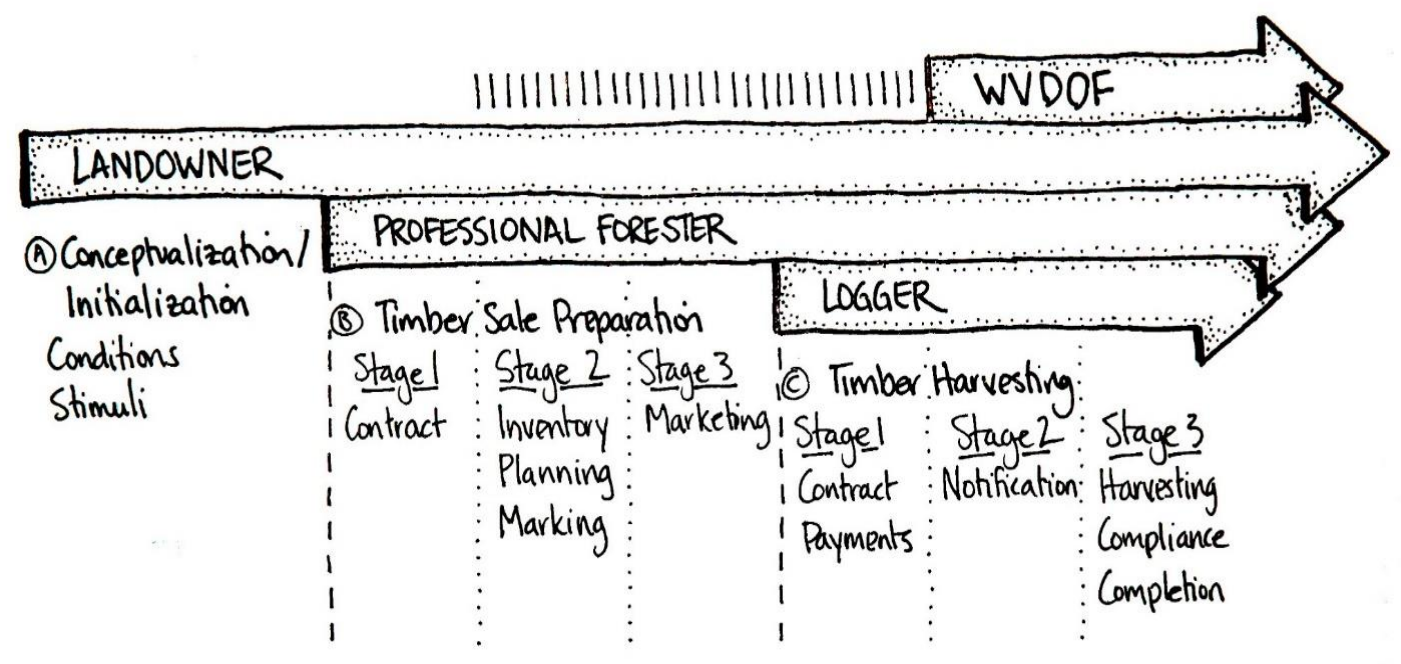

Figure 1. Four party Scenario Timber Transaction Process. Figure Courtesy of D. McGill, West Virginia University Extension Service.

During all of these phases, extension literature attempts to address and give guidance to FFO's about certain activities that occur and need to be managed during the timber sale. As far back as the Clarke-McNary Act of 1924 University Extension programs added forestry into its educational programs (Barden et al. 1996). Much of this information was meant to help 
landowners to plan and implement management activities. This literature suggests FFOs determine property and harvest boundaries, visit the site and communicate with parties who are involved, create a written contract with involved parties, hire a forester or at least communicate with other professionals for guidance (Heiligmann et al. 1986, Grotta 2014, Grushecky et al. 2012, Bowers 2007).

Before a harvest should even begin, it is recommended that FFOs establish goals and a management plan for their property. Goals must account for time, money, site, and equipment constraints when they are being created (Grotta et al. 2014). A forest management plan describes the property, lists goals, and roughly defines how the FFO plans to accomplish these goals (Grotta et al. 2014). A study of FFO satisfaction in West Virginia found that $79 \%$ of landowners did not have a forest management plan. However, on a positive note most of the FFOs did have objectives and goals for their property (McGill et al. 2006).

Foresters, whether state, procurement, or private consultants can be a wealth of information and a connection to other professionals Heiligmann et al. 1986, Bowers 2007, Grotta 2014 Rickenbach 2018). FFOs are encouraged to regularly visit the harvest site and communicate with the operators and having a forester can help the FFO understand what is happening and help answer questions and concerns (Heiligmann et al. 1986, Bowers 2007, Grotta 2014 Rickenbach 2018). Consulting foresters are highly recommended due to their propensity to harvest trees that are considered a high value species or timber that will become the future saw timber of the stand (Moss et al. 2013). Consulting foresters are hired and to represent and protect the FFO and their property

Logging companies can have a diverse structure, equipment types and availability to harvest and complete FFO goals. For example, the typical crew can range from 2 to 9 employees 
and can be independent contractors, contract or company logging crews (Grushecky et al. 2012). Transactions can vary depending on who and what are involved, landowner goals, and the lay of the land. Equipment used for the harvest can affect the landowner's satisfaction with the harvest as well. Sounds, damage to residual trees, mess, speed of the harvest and a host of other issues can positively or negatively affect a harvest. A longer than expected harvest can affect the amount income received due to fluctuations of the market (Bower et al. 2007).

\section{Satisfaction}

Satisfaction is considered a non-financial measurement of a company's performance. It can be said that it is a reliable indicator of a company's future (Chen et al. 2009). Perceived quality is the client's judgement of how well the company performed (Parasuraman et al. 1988). Service quality is judged by a sense of standards or ideal services, whereas satisfaction is judged by experiences (Lee et al. 2014). Satisfaction is a mental state that results from confirmation or disconfirmation of expectations and prior feelings about experiences with a service (Parasuraman et al. 1988). Harvesting out of bounds, damage to residual trees, harvesting unmarked trees, and other issues can all cause a deviation from FFO expectations resulting in dissatisfaction. Negative reviews or experiences cause a consumer to avoid a product or service (Weiner 2000).

Determining issues and going the extra mile to correct them as best as possible gives the client a sense of gratitude and may cause them to recommend those involved (Weiner 2000).

\section{Purpose:}

Previous research has shown that five themes emerge from interviews with West Virginia FFOs who had recently harvested timber. Items such as hiring a forester, previous knowledge of what occurs during a harvest, trusting the parties that were involved in the harvest all impacted the outcome of the harvest. Hiring a forester or being prepared for the sale could 
positively impact a timber sale, whereas not trusting the forester or the logging company would negatively impact the outcome of the timber sale (Maltempie 2017).

FFOs and forestry professionals could both benefit by knowing how the various attributes timber transactions interact with and impact satisfaction. Knowing this, they could then focus on poor performing but essential attributes to improve the quality of future timber sales.

The goal of this research is to determine important aspects of a successful timber transaction. Specifically, research questions included:

Q1. What attributes of a timber sale are indicators of overall FFO satisfaction with their timber sale?

Q2. How important are these attributes to an FFO and how well they are being performed during a timber sale? 


\section{Chapter III: Methods}

A survey of West Virginia FFOs formed the basis of this study designed to explore how overall FFO satisfaction is influenced by events and conditions that occur during a timber transaction. A mailed questionnaire provided a representative sample of FFO experiences with their recent timber sales.

\section{FFO selection process}

A list of FFOs who had recently harvested timber from their properties was obtained from the West Virginia Logging Operations Notification Inspection and Enforcement system (LONIE). The system is maintained by the West Virginia University Appalachian Hardwoods Center and the West Virginia Division of Forestry (WVDOF). LONIE was developed as a tool for the WVDOF to comply with the WV Logging Sediment Control Act (LSCA) by creating a registry of logging operations and inspection findings. Logging operators are required to send a notification to LONIE within three days of beginning a harvest. The LONIE database includes data such as harvesting location, parties involved, loggers license number, client contact information, and when and where the harvest would occur (Spong 2013).

LONIE contains statewide records of both FFOs and other landowner types that have filed timbering notifications. Landowners selected to participate in this survey were required to be an FFO and have filed a timber notification form between November of 2012 and November of 2019. At the time of this study, LONIE contained a total of 13,009 entries. Landowner classes were sorted to remove non-FFOs. Duplicates were removed if the FFO's owned multiple properties or had performed multiple harvests within the time period of interest. Keywords such as trusts, company, corporation, limited or limited liability company were used to find and remove possible non-FFO entries in the LONIE database. The LONIE file contained entries that 
went back as far as 2012. The entries were sorted by ending date to eliminate harvests that had not been completed.

Memory and the amount of time that passes following an event could be considered a problematic issue with the accuracy of FFO responses. However, it was assumed that harvesting can be considered a "significant alteration" that acts as a reminder and inhibits forgetting (Sudman et al 1973). We also used notification date as an explanatory variable to account for this time since harvesting consideration.

After filtering for FFOs, there were 4,331 properties with notification forms making up the sampling frame. To obtain a $95 \%$ confidence and a margin of error of 0.05 for our questionnaire items, 354 FFO responses were needed from the population (Krejcie et al. 1970). Based upon previous questionnaire response rates 25 percent was commonly achieved, 1,349 FFOs were randomly chosen as participants.

\section{Data Collection}

The questionnaire contained sections related to the elements of timber sales based on peer-reviewed and extension-based technical publications. These publications contain recommendations for FFOs interested in harvesting timber or otherwise managing their properties. Some of the recommendations include the type of forestry professionals to contact, professionals who can administer timber sales from start to finish. Details of items related to the planning, layout, and logging are found in many helpful extension documents (Bowers et al. 2007, VDOF 2014, Grotta et al. 2014, Rickenbach et al. 2018) and give landowners some idea about what to expect in a prospectus, on a contract, during the timbering, and following reclamation. 
The questionnaire (Appendix A) was organized around six different sections: 1) property management, 2) decision to sell timber, 3) planning the timber harvest, 4) logging operations, 5) post-harvest results, and 6) demographics. Generally, items that would be used as response variables in our analyses were taken from section 5, post-harvest results (Table 1). These are questions that are related to landowner satisfaction with their timber transaction. Items in the questionnaire that would serve as explanatory variables - descriptors of the property, planning, timbering, and demographics of each timbering transaction - are in the other five sections (Table 2). Explanatory variable types included ordinal variables derived from Likert scales and importance/performance items, opened-ended questions, categorical, and continuous variables.

Table 1. Post-harvest satisfaction attributes serving as response variables.

\begin{tabular}{ll}
\hline Variable & Description \\
satrevrec & $\begin{array}{l}\text { Satisfied with the amount of revenue. 1= very dissatisfied, } \\
\text { 4= very satisfied } \\
\text { sattimbersale }\end{array}$ \\
$\begin{array}{l}\text { Satisfied with the entirety of the timber sale. } 1=\text { very } \\
\text { dissatisfied, } 4=\text { very satisfied }\end{array}$ \\
Satisfied with contract. $1=$ very dissatisfied, $4=$ very \\
satisfied \\
Satgoals
\end{tabular}


Table 2. Timber transaction attributes serving as explanatory variables.

\begin{tabular}{|c|c|}
\hline Variable & Definition \\
\hline residence & FFO residence. $1=$ current residence, $0=$ not currently residing \\
\hline lntotac & Natural Log of FFO owned acreage \\
\hline firstharv & FFO's first harvest. $1=$ first harvest $0=$ multiple harvest (veteran) \\
\hline ownertype & $\begin{array}{l}\text { Type of family owner split into unique owner (individual) or famunit } \\
\text { (joint with spouse and family). }\end{array}$ \\
\hline incenttax & $\begin{array}{l}\text { Participation in farm or managed timberland tax. } 0=\text { yes timberland, } \\
\text { agriculture or both } 1=\text { no }\end{array}$ \\
\hline forester & $\begin{array}{l}\text { Forester data from LONIE, contains Consultant, Procurement, and State } \\
\text { forester. } 1=\text { there was a forester associated with sale, } 0=\text { no forester } \\
\text { associated with sale }\end{array}$ \\
\hline noteyear & Year the harvest was accomplished. Continuous variable. \\
\hline plan & FFO management plan for property $1=$ plan 0 no plan \\
\hline guidance & FFO's receive guidance or advice on the best way to harvest no $=0$ yes $=1$ \\
\hline events & FFO decision to sell timber $0=\mathrm{I}$ was asked to sell, $1=\mathrm{I}$ first decided to sell \\
\hline Decisionbi & $\begin{array}{l}\text { Q10 combination of reasons why the FFO decided to sell their timber } 0= \\
\text { disagree } 1=\text { agree }\end{array}$ \\
\hline Knewbi & $\begin{array}{l}\text { Q12 combination of variables involving landowner previous knowledge } \\
\text { related to land management } 0=\text { disagree } 1=\text { agree }\end{array}$ \\
\hline Discussbi & $\begin{array}{l}\text { Q12 combination of variables involving landowner communication with } \\
\text { family and neighbors for harvest } 0=\text { disagree } 1=\text { agree }\end{array}$ \\
\hline adeqparty & $\begin{array}{l}\mathrm{I}-\mathrm{P}=\mathrm{D} \text { When } \mathrm{I} \text { and } \mathrm{P} \text { are the same or } \mathrm{P} \text { is higher than the party's } \\
\text { involvement were adequate, if I was less than } \mathrm{P} \text {, there was a lack of } \\
\text { satisfaction. }\end{array}$ \\
\hline adeqplan & $\begin{array}{l}\mathrm{I}-\mathrm{P}=\mathrm{D} \text { When } \mathrm{I} \text { and } \mathrm{P} \text { are the same or } \mathrm{P} \text { is higher than the planning of the } \\
\text { harvest was adequate, if I was less than } \mathrm{P} \text {, there was a lack of } \\
\text { satisfaction. }\end{array}$ \\
\hline adeqcomm & $\begin{array}{l}\mathrm{I}-\mathrm{P}=\mathrm{D} \text { When } \mathrm{I} \text { and } \mathrm{P} \text { are the same or } \mathrm{P} \text { is higher than the communications } \\
\text { between parties were adequate, if I was less than } \mathrm{P} \text {, there was a lack of } \\
\text { satisfaction. }\end{array}$ \\
\hline adeqoperations & $\begin{array}{l}\mathrm{I}-\mathrm{P}=\mathrm{D} \text { When } \mathrm{I} \text { and } \mathrm{P} \text { are the same or } \mathrm{P} \text { is higher than the operations were } \\
\text { adequate, if I was less than } \mathrm{P} \text {, there was a lack of satisfaction. }\end{array}$ \\
\hline adeqindex & $\begin{array}{l}\text { Performance adequacy index of adeqparty, adeqplan, adeqcomm, } \\
\text { adeqoperations }\end{array}$ \\
\hline selltype & type of timber sale $1=$ Sealed bid, $2=$ negotiated sale, 3 paid on shares \\
\hline Again & Landowner decision to sell timber again in the future. $0=$ no $1=$ yes \\
\hline Addact & $\begin{array}{l}\text { FFO have to perform or have logging company perform additional work } \\
\text { after the harvest } 0=\text { no } 1=\text { yes }\end{array}$ \\
\hline Gender & Gender of respondents \\
\hline Age & Age in years of respondents \\
\hline College & Education level of FFOs. $0=$ Some high school/high school \\
\hline Satisbi & Response variable of overall mean of satisfaction. \\
\hline
\end{tabular}


Two additional variables were extracted from the LONIE data that were not included in the questionnaire. Noteyear was a variable designating the year that the FFO or logging company notified the WVDOF of their intention to begin logging. Forester was the second variable confirming that either a procurement or consulting forester was associated with the timbering operation (Table 2).

Each of these attribute sections were designed to serve as a part of a model to explore satisfaction as a function of the attributes that occur during each phase of a timber harvest. The generalized model was:

Satisfaction $=f($ Management of your property + Deciding to sell timber + Planning the timber harvest + The logging operations + Demographics).

\section{Deployment}

Once completed the questionnaire was submitted for review to three West Virginia University forestry faculty members and to the West Virginia Division of Forestry Assistant State Forester for Logging Compliance. Updates were made based upon comments and suggestions made during this first review. The updated questionnaire was then mailed to three FFOs known by the research team and who had recently harvested timber. Using feedback from reviewers, modifications were made to streamline and simplify the questionnaire.

The questionnaire was submitted to the West Virginia University Internal Review Board and was approved for an expedited research exemption. Deployment was based on a modified protocol recommended by Dillman (2000). An initial mailing of the questionnaire occurred on January 10, 2020. FFOs who had not responded received a follow-up reminder via postcard on January 27, 2020, with a second mailing of the questionnaire sent on February 24, 2020. 


\section{Data Analysis}

\section{Coding process}

Open ended questions were used in the questionnaire to elicit responses from FFOs that may have otherwise not been revealed within the confines of the questionnaire. FFO responses were coded based on themes or patterns emerged from each question. Emergent categories were determined by reading through the responses to find themes or issues that recurred within the data. Categories were then defined after the data had been read (Renner et al. 2003). Relative importance of the themes was used to bolster or to understand the quantitative questions in the analysis process.

\section{Importance Performance Analysis}

Importance-performance analysis (IPA) was used to determine what attributes of a transaction are important to a customer - here, the landowner - and how adequately they are being performed. The difference between the importance of a transaction attribute and the performance or delivery of that attribute serves as an indicator of the adequacy of the attribute. The IPA sections in this questionnaire were 1) parties involved in the sale, 2) planning the sale, 3) FFO communication, and 4) harvest operations. Each of these sections had a set of items representing various timber sale attributes. For each attribute, the respondent was asked to rank both the importance of the attribute and the performance adequacy of the attribute. Again, many of these attributes were created from information contained in various extension and research publications that were developed to promote landowner education about timber sales. In this way, the IPA was geared to identify high and low performing elements that occur in timber transactions. 
Following methodology suggested by Deng et al. (2018), importance-performance values for the attributes in each section were scaled with respect to the attributes within the respective section. Restated, the overall means of each section's importance and performance values were subtracted from each individual attribute's mean importance and performance values. The results were then plotted using performance as the domain (x-axis) and importance along the range (yaxis) (Figure 1) (Ennew et al. 1993, Deng et al. 2018).

A desirable feature of IPA is that the attributes are be plotted and given a visual display in graphical form (Martilla et al. 1977, Oh 2000). The IPA graph is divided into four quadrants, each with a different interpretation: quadrant 1-- important with good performance, quadrant 2-possible overkill, quadrant 3--low priority, and quadrant 4-- important with poor performance (Figure 2) (Oh 2000).

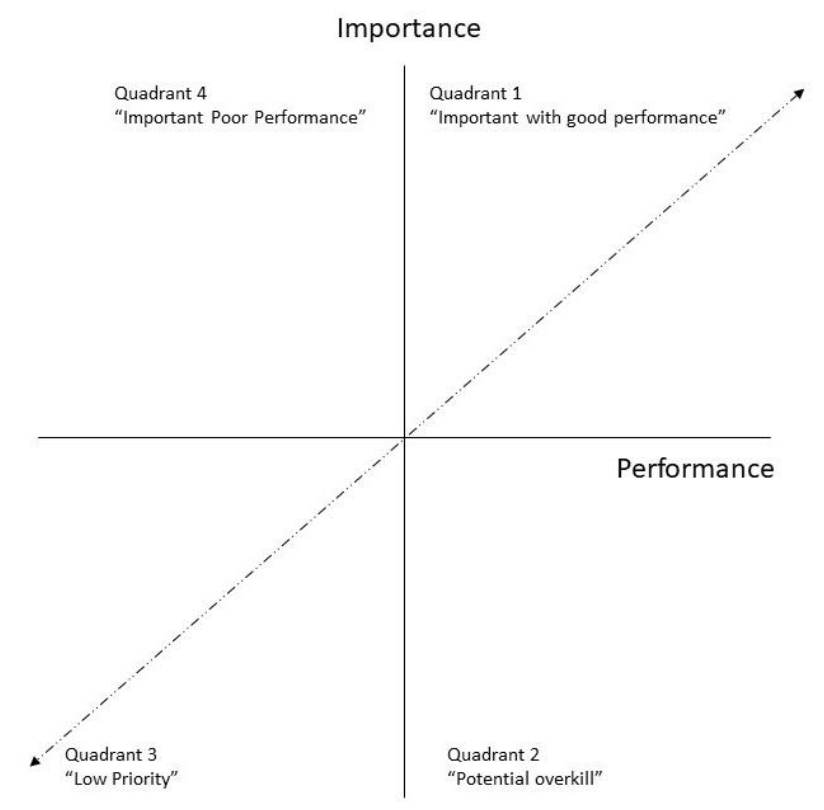

Figure 2. Importance-Performance Analysis grid (adapted Martilla et al. 1977 and Oh 2000). 
Alternatively, instead of viewing the attribute only by looking at the quadrant it is in, the adequacy of the attribute can be assessed by its location in relation to the iso-rating line. The iso-rating line is the line where importance equals performance (Abalo et al. 2007, Deng et al 2018), that is, it is the location where the customer finds the transaction perfectly adequate. In this format, the quadrants still exist but they have been re-arranged (Figure 3). Attributes found above the iso-rating line where importance is greater than performance are considered inadequate. Everything below the iso-rating line where performance is greater than importance is considered to be low priority, possible overkill, or keep up the good work.

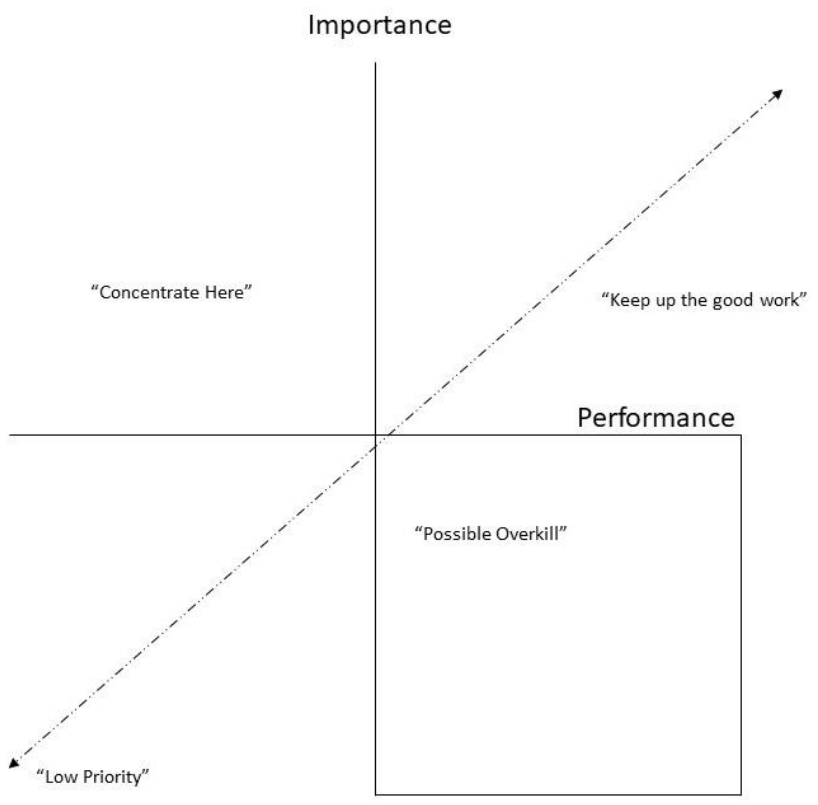

Figure 3. Importance-Performance Analysis grid (adapted from Abalo et al. 2007)

\section{Gap Analysis}

A "gap" analysis was performed as a secondary method to quantify which attributes were being performed adequately and which inadequately. The mean of each importance-performance attribute was used to determine the "gap". The mean importance rating for each attribute was 
subtracted from the corresponding mean performance rating. If the difference was positive, then the attribute of the timber sale was considered to have been performed adequately, that is, performance was greater than importance. If the outcome was negative, the item was performed inadequately and would need to be addressed in the future (Chaudhary et al. 2016). A paired $t$ test was conducted for each of the IPA's importance-performance attributes to determine if there was a significant gap.

\section{Variable Reduction}

The questionnaire contained a total of 61 explanatory variables and 6 response variables. Principle components analysis (PCA) was used to examine the underlying correlation structure of Likert and IPA questions for opportunities to reduce the number of variables used in the analysis. This was done for both response (Table 1) and explanatory variables (Table 2). The ultimate objective of the PCA is to reduce the number of variables while preserving as much information in the data as possible (Jolliffe et al. 2016).

The fundamental idea for PCA was to examine whether each attribute (or questionnaire item) in a section was correlated with any or all of the others. If a high degree of correlation existed, there was no need to use all of the variables to represent the section theme. Protocol for PCA required section attributes to be subjected to multiple tests, beginning with Spearman Rank Correlation tests to determine the degree of correlation among attributes within a section. If the test suggests correlation exists, then some redundancy is present in the section's attributes and thus steps can be taken to condense the number of attributes in the section. If variables are uncorrelated, then each item can be thought to represent a separate idea and PCA does not need to continue. Bartlett's test of sphericity was used to test the correlations with the null hypothesis that there are no common factors. Rejecting the null hypothesis suggests that some of the 
section's attributes are correlated. If the null hypothesis is rejected, we then subjected the section's attributes to Kaiser's measure of sample adequacy.

Kaiser's measure of sample adequacy (MSA) was used to quantify correlation between variables. When MSA is greater than 0.5 , some correlation exists within the selected variables. When MSA equals 1.0, each variable is a predictor of other variables and the section of variables can be condensed. If MSA is below 0.5 then PCA is performed.

PCA was then used to check the internal consistency and evaluate the opportunity to reduce the number of variables within a section. Parallel analysis lent evidence as to the number of significant components in the section by comparing eigenvalues of randomly generated data with data from a section of timber transaction attributes (O'Conner 2000). Finally, Cronbach's $\alpha$ was used to test for internal consistency of any set of summated variables.

\section{Variable Reduction Results}

There was a high degree of correlation in all variables of the questionnaire. Few instances were found to indicate the sections of the questionnaire had any underlying variables that might describe variation within the section. This led to the decision to create composite variables made up of the mean of all items for each section. However, attributes within the section on prior knowledge about timber harvesting were split into the two separate composite variables Discuss and Knew (Table 3, Table 4). Knew consisted of attributes eliciting responses on previous knowledge such as minimizing logging erosion and having goals for my property. Discuss consisted of attributes eliciting responses on logging discussions held with family and neighbors. 
Table 3. Details of "Knew and Discuss" attribute list from Question 12 of the survey

12. Please read the following statements and mark how strongly you agree or disagree.

\begin{tabular}{|c|c|c|c|c|}
\hline Before I sold timber I... & $\begin{array}{l}\text { Strongly } \\
\text { Disagree }\end{array}$ & Disagree & Agree & $\begin{array}{l}\text { Strongly } \\
\text { Agree }\end{array}$ \\
\hline ... knew about ways to minimize logging erosion. & 1 & 2 & 3 & 4 \\
\hline ...was able to identify invasive plant species. & 1 & 2 & 3 & 4 \\
\hline ... knew that a contract was important. & 1 & 2 & 3 & 4 \\
\hline $\begin{array}{l}\text { had a clear set of goals established for my } \\
\text { property. }\end{array}$ & 1 & 2 & 3 & 4 \\
\hline ...discussed selling timber with my neighbors. & 1 & 2 & 3 & 4 \\
\hline ..discussed selling timber with my family. & 1 & 2 & 3 & 4 \\
\hline $\begin{array}{l}\text {...was aware of my potential liability to logging } \\
\text { and logging related injuries. }\end{array}$ & 1 & 2 & 3 & 4 \\
\hline
\end{tabular}

As mentioned, PCA using Varimax rotation provided evidence for two separate components from the section on prior knowledge (Table 4). Parallel analysis (Figure 4) confirmed that the prior knowledge section could be split into two factors. Two other attributes, previous knowledge and discussion variables were able to stand as separate variables (Table 4). By looking at factor 1 and 2 we used a 0.5/0.2 rule to determine which variables stood out and could be separated into composite variables (Matsunga 2011).

The first component knew included the items: knew about ways to minimize logging erosion; was able to identify invasive plant species; knew that a contract was important; had a clear set of goals for my property; was aware of my potential liability to logging and logging related injuries (Table 3). The second component discuss included: discussed selling timber with my neighbors; discussed selling timber with my family (Table 3). Each of these components were made into composite variables. 
Table 4. Factor Structure for PCA related to variables Discuss and Knew

\begin{tabular}{lccccc}
\hline Variable & PC & PC Name & Factor 1 & Factor 2 & $\begin{array}{c}\text { Cronbach's } \\
\alpha\end{array}$ \\
\hline $\begin{array}{l}\text { Discussed selling timber with } \\
\text { neighbors }\end{array}$ & 1 & Discuss & & 0.75446 & 0.43 \\
$\begin{array}{l}\text { Discussed selling timber with } \\
\text { family }\end{array}$ & 1 & Discuss & & 0.69173 & \\
$\begin{array}{l}\text { Knew of ways to minimize } \\
\text { erosion }\end{array}$ & 2 & Knew & 0.75264 & & 0.70 \\
$\begin{array}{l}\text { Able to identify Invasive plants } \\
\text { Knew importance of a contract }\end{array}$ & 2 & Knew & 0.74688 & \\
$\begin{array}{l}\text { Clear set of goals } \\
\text { Aware of liability to logging }\end{array}$ & 2 & Knew & 0.48975 & \\
related injuries & 2 & Knew & 0.6288 & \\
\hline
\end{tabular}

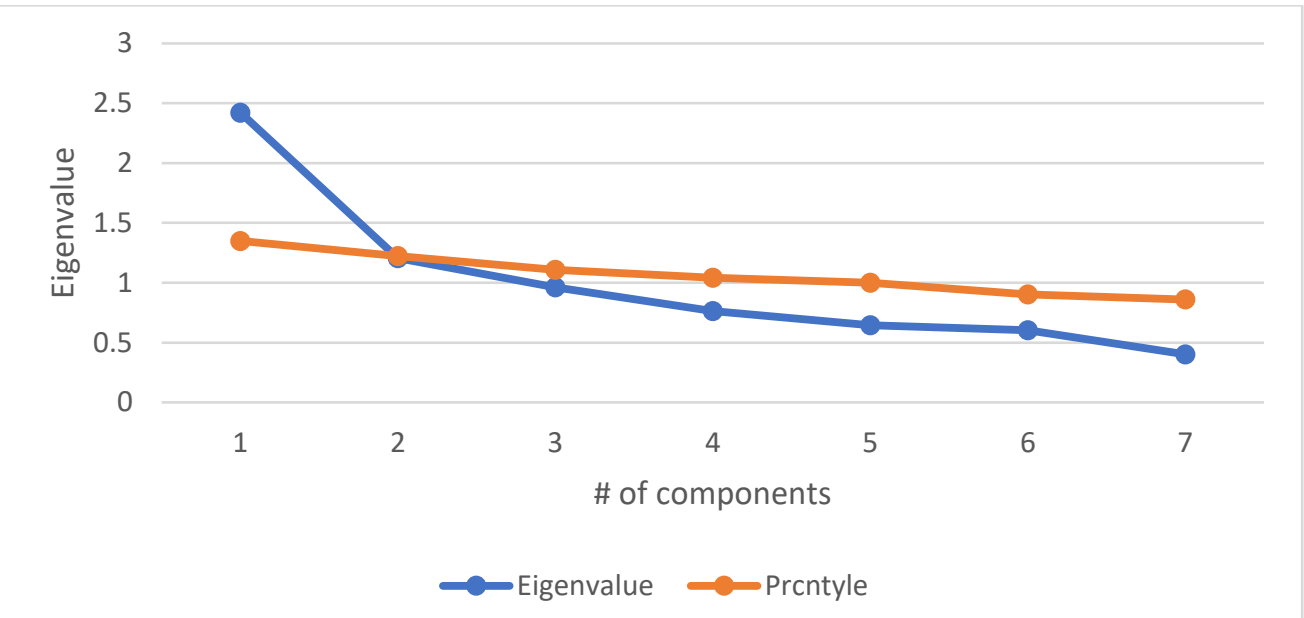

Figure 4. Parallel analysis with Eigen values generated from attributes of question 12 Management knowledge.

\section{Univariate logistic regression}

Univariate logistic regression was used to assess the correlation and strength of relationships between timber transaction attributes (explanatory variables) and the measure of overall satisfaction with the timber transaction. Each variable was regressed on the binary 
satisfaction metric satisbi. PROC Logistic was used to generate odds ratio and p-values for each univariate model.

\section{Adequacy Index}

PCA and initial univariate logistic regressions found significant correlation within IPA sections of planning (adeqplan), communications (adeqcomm), and operations (adeqoperations) and strong correlation with the overall satisfaction response variable, satisbi (Table 2). Because of the significant and ubiquitous amount of correlation among the explanatory variables (timber transaction attributes), an adequacy index was created as a representation of all IPA attributes that occur during a transaction.

The adequacy index was created by computing each section's mean gap (performance importance) then converting it into a binary variable. If the mean was greater than or equal to 0 then section was deemed adequate and rated 1 . If the section mean was less than 0 then the section was deemed inadequate and rated 0 . The adequacy index is a summation of the binary variables from the planning, communications, and operations sections. Hence, the adequacy index ranged from 0 , meaning there were no sections that were deemed adequate to 3 with means that all three sections were adequate.

\section{Modeling satisfaction as a function of landowner and timber sale attributes}

The Akaike Information Criterion (AIC) was used to establish which and the number of the explanatory variables that best account for the variation in a landowner's overall post-harvest satisfaction. The AIC can identify the most parsimonious models that provide the least amount of information loss (Mazerolle 2006). Stepwise logistic regression retained explanatory variables 
with a significance level of 0.99 and removed variables with a significance level 0.95 . This allowed all variables to be tested in this variable selection process. At each step of the variable selection process, the AIC was calculated. The optimal number of explanatory variables to generate the most parsimonious model was the model with the lowest AIC value. The regression process and corresponding AIC values suggested a two-covariate model.

A best subsets logistic regression was then used to determine the best combination of explanatory covariates based upon the outcome of the AIC selection (King 2003). All explanatory variables (Table 2) were included in the best subsets logistic regression. The best model was chosen based on the highest chi-square values for a model of a given number of covariates.

Variables dealing with willingness to harvest again and parties involved were removed from the model. Willingness to harvest again was removed due to the majority of coded responses lacking a satisfaction-based reason as to why or why not they planned to harvest again, that is, many simply were too old or didn't have any timber left. Parties involved was removed from the adequacy index of planning, communication and operations due to a low number of responses. The rest of the variables were allowed to remain in the best subsets logistic regression.

Goodness of fit for the logistic regression models was assessed using deviance goodnessof-fit statistics and Receiver Operator Characteristic curve statistics. Deviance compares the results of the best subsets logistic regression to a saturated model that includes all covariates. In the deviance test, the null hypothesis is that the fitted model is correct. 


\section{Chapter IV: Results}

In total, 1349 questionnaires were sent to West Virginia FFOs with 257 completing the questionnaire. This resulted in a $19 \%$ response rate. The cooperation rate - the number of questionnaires filled out divided by the number returned (that include some refusals and blanks) was 75\% (AAPOR 2016). Ninety-four questionnaires were returned blank, 177 questionnaires were returned due to bad addresses and 34 were deemed ineligible due to either being not considered an FFO or the FFO was deceased (Wiseman 2003).

\section{Demographics}

Eighty percent $(80 \%)$ of the respondents were male (Table 5). The plurality of respondents was aged 65-74 (35\%) and 35\% had completed high school. Twenty four percent had an income of $\$ 25,000-\$ 49,000$ per year (Table 5). Most respondents $(58 \%)$ were enrolled in either the Managed Timberland or Farmland incentive tax programs. 
Table 5. FFO Demographic Characteristics by number (n) and proportion (\%) of respondents.

\begin{tabular}{|c|c|c|}
\hline Variable & $n$ & $\%$ \\
\hline \multicolumn{3}{|l|}{ Gender } \\
\hline Male & 213 & 80 \\
\hline Female & 52 & 20 \\
\hline \multicolumn{3}{|l|}{ Age } \\
\hline $18-24$ & 1 & 0.4 \\
\hline $23-34$ & 2 & 0.8 \\
\hline $35-44$ & 19 & 7 \\
\hline $45-54$ & 27 & 10 \\
\hline $55-64$ & 59 & 22 \\
\hline $65-74$ & 92 & 35 \\
\hline $75-84$ & 48 & 18 \\
\hline 84 or greater & 17 & 6 \\
\hline \multicolumn{3}{|l|}{ Gross Income } \\
\hline$\$ 15,000-\$ 24,999$ & 25 & 12 \\
\hline$\$ 25,000-\$ 49,999$ & 52 & 24 \\
\hline$\$ 50,000-\$ 74,999$ & 49 & 23 \\
\hline$\$ 75,000-\$ 99,000$ & 36 & 17 \\
\hline$\$ 100,000-\$ 199,999$ & 37 & 17 \\
\hline$\$ 200,000$ or more & 15 & 7 \\
\hline \multicolumn{3}{|l|}{ Education } \\
\hline Some High school & 7 & 3 \\
\hline High school & 92 & 35 \\
\hline Associate's degree & 17 & 7 \\
\hline Bachelor's degree & 51 & 20 \\
\hline Master's degree & 53 & 20 \\
\hline Ph.D. or higher & 13 & 5 \\
\hline Trade school & 25 & 10 \\
\hline Prefer not to say & 2 & 0.8 \\
\hline
\end{tabular}

Respondents owned a mean of 153.3 total acres and the majority described their most recent harvest as their first harvest $(61 \%)$. The majority of respondents lived on their property $(48 \%)$ and did not lease any part of their property $(76 \%)$. However, of the $24 \%$ that did lease their land, most did so for agricultural purposes like pasture and hayfields. Similarly, most reported their property was taxed as farmland (43\%) and $3.4 \%$ of respondents were taxed for 
both farmland and managed timberland. When asked about written plans for their property, $69 \%$ did not have a written plan.

When planning their harvest, the majority of FFOs received some form of guidance $(52 \%)$, mostly from foresters or other industry professionals. Two primary concerns that respondents had for their harvest included the condition of their property (23\%) after their harvest and financial issues (21\%). Respondents visited the logging site either daily (29\%) or weekly (28\%). However, $11 \%$ of respondents never visited the site.

Out of 250 respondents, $50 \%$ plan to harvest again and $50 \%$ do not plan to harvest in the near future. Of those who do not plan to harvest again, $24 \%$ stated their age would not permit them to harvest and $22 \%$ did not have enough timber to harvest again. However, $16 \%$ of respondents said they would not harvest due to a bad experience. Seventy-five percent of FFO's did not have any additional work done to their property after the harvest. Of those FFOs that did have additional work performed, the majority (31\%) had road work performed, followed by reseeding (30\%).

The majority of respondents expressed that the best part of their harvest was the income from the harvest (32\%), followed by property management (16\%), and finally, the honesty and professionalism of parties involved (13\%). Thirty-one percent of respondents stated there were no negative aspects to their harvest. However, $21 \%$ stated that poor reclamation was the most negative aspect of their sale.

\section{Gap Analysis}

Many significant differences were found in the paired-sample $t$-tests used in the gap analysis (Table 6). The overall mean values for performance and importance were 3.04 and 3.33 respectively. Harvesting in agreed upon areas had the highest rating for importance (3.77) 
and how the FFO would receive payment was rated highest in performance (3.55). Notification of WVDOF visits and findings was rated the lowest in both importance (2.64) and performance (2.13).

Table 6. Evaluation of performance (P) and importance (I) for parties involved in timber sales.

\begin{tabular}{|c|c|c|c|c|c|}
\hline \multirow[b]{2}{*}{ Item } & \multicolumn{2}{|c|}{ Mean } & \multirow[b]{2}{*}{ gap (I-P) } & \multirow[b]{2}{*}{$t$} & \multirow[b]{2}{*}{$p$} \\
\hline & $\mathrm{P}$ & $\mathrm{I}$ & & & \\
\hline \multicolumn{6}{|l|}{ Parties } \\
\hline Consulting Forester & 3.19 & 3.31 & 0.12 & -2.68 & 0.008 \\
\hline Procurement Forester & 2.80 & 3.08 & 0.28 & -3.44 & 0.001 \\
\hline State Forester & 2.72 & 2.94 & 0.22 & -2.21 & 0.028 \\
\hline Logger & 2.97 & 3.52 & 0.55 & -6.72 & $<0.000$ \\
\hline \multicolumn{6}{|l|}{ Planning } \\
\hline Treessold & 3.30 & 3.61 & 0.31 & -4.87 & $<0.000$ \\
\hline Boundaries & 3.48 & 3.67 & 0.19 & -3.41 & $<0.001$ \\
\hline Offlimits & 3.28 & 3.45 & 0.17 & -2.77 & 0.006 \\
\hline Equipment & 3.02 & 2.80 & -0.22 & -8.08 & $<0.000$ \\
\hline Roads & 3.07 & 3.23 & 0.16 & -2.24 & 0.026 \\
\hline Goals & 2.90 & 3.27 & 0.37 & -5.22 & $<0.000$ \\
\hline Taxes & 2.90 & 3.02 & 0.12 & -1.78 & 0.076 \\
\hline BMPS & 2.85 & 3.15 & 0.3 & -4.49 & $<0.000$ \\
\hline Payment & 3.55 & 3.63 & 0.08 & -2.12 & 0.035 \\
\hline \multicolumn{6}{|l|}{ Communication } \\
\hline Welcome & 3.29 & 3.33 & 0.04 & -0.26 & 0.796 \\
\hline Concerns & 3.29 & 3.51 & 0.22 & -3.47 & 0.001 \\
\hline Loads & 2.47 & 2.71 & 0.24 & -2.76 & 0.006 \\
\hline Problems & 2.58 & 3.04 & 0.46 & -5.90 & $<0.000$ \\
\hline WVDOF & 2.13 & 2.64 & 0.51 & -5.41 & $<0.000$ \\
\hline Prices & 2.33 & 2.76 & 0.43 & -5.20 & $<0.000$ \\
\hline \multicolumn{6}{|l|}{ Logging Operations } \\
\hline Agreedtrees & 3.43 & 3.72 & 0.29 & -5.06 & $<0.000$ \\
\hline Areas & 3.52 & 3.77 & 0.25 & -4.53 & $<0.000$ \\
\hline Gates and Roads & 3.52 & 3.66 & 0.14 & -2.88 & 0.004 \\
\hline BMPSfoll & 3.16 & 3.58 & 0.42 & -6.13 & $<0.000$ \\
\hline Ruts & 3.00 & 3.53 & 0.53 & -7.34 & $<0.000$ \\
\hline Mulched & 2.91 & 3.48 & 0.57 & -7.44 & $<0.000$ \\
\hline Residtrees & 3.05 & 3.62 & 0.57 & -7.19 & $<0.000$ \\
\hline Smoothed & 3.08 & 3.60 & 0.52 & -7.15 & $<0.000$ \\
\hline Follcont & 3.26 & 3.70 & 0.44 & -6.58 & $<0.000$ \\
\hline Mean & 3.04 & 3.33 & & & \\
\hline
\end{tabular}

Paired $t$-tests showed that 26 out of 28 pairs were significantly different with only equipment types $(-0.22)$ being significantly lower in performance than in importance. All of the other 
attributes were rated significantly higher in performance than in importance.

\section{Importance-performance analysis}

Figure 5 displays attributes from parties involved in the harvest. Judging by the quadrant, the logging company and consulting forester are both located in the "Keep up the good work" quadrant. The Logger has the highest level of importance. However, State and

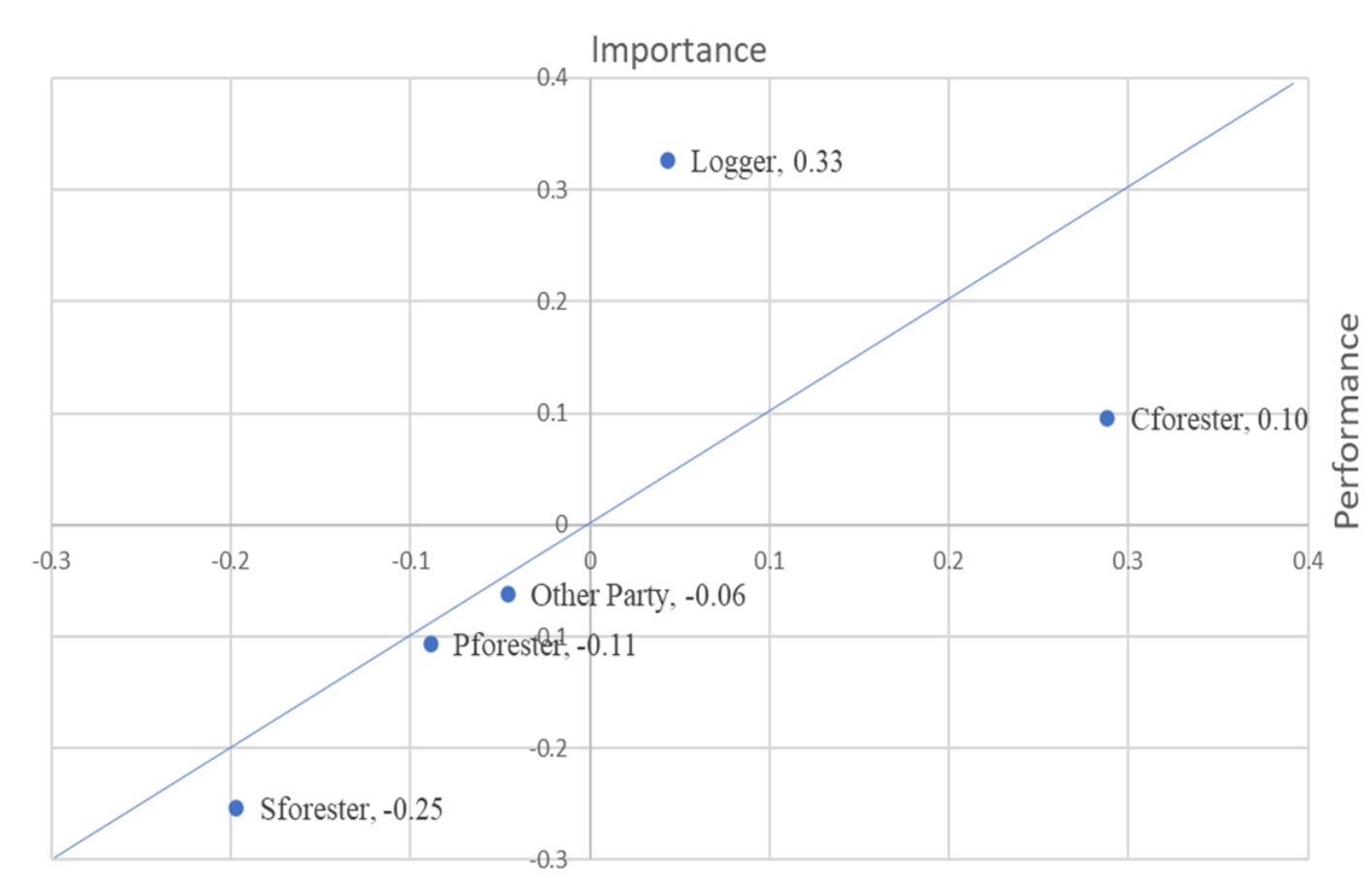

Procurement foresters are both in the "Low Priority" quadrant along with Other Party.

Figure 5. Importance-Performance Analysis of Parties involved

Alternatively, if evaluated with respect to the iso-rating line, all parties except the logger fall below the iso line and perform well. The Logger lies above the iso-rating line and shows a need for improvement.

Attributes dealing with planning the harvest have a high degree of variability (Figure 6). Attributes found in the "Keep up the good work" quadrant were determining boundaries, 
payments, trees to be sold, and areas that are off-limits. However, planning how taxes would be paid, Best Management Practices (BMPs), equipment, goals, and roads as were described as “Low Priority”.

Alternatively, the attributes goals, trees to be sold, boundaries, and BMPs are all found above the iso-rating line. This suggests there is room for improvement and should be focused upon. Payment, taxes, and equipment types are found below the iso-rating line suggesting they are being performed adequately. Off-limits areas and planned roads are considered adequate, their performance matches the FFO's importance.

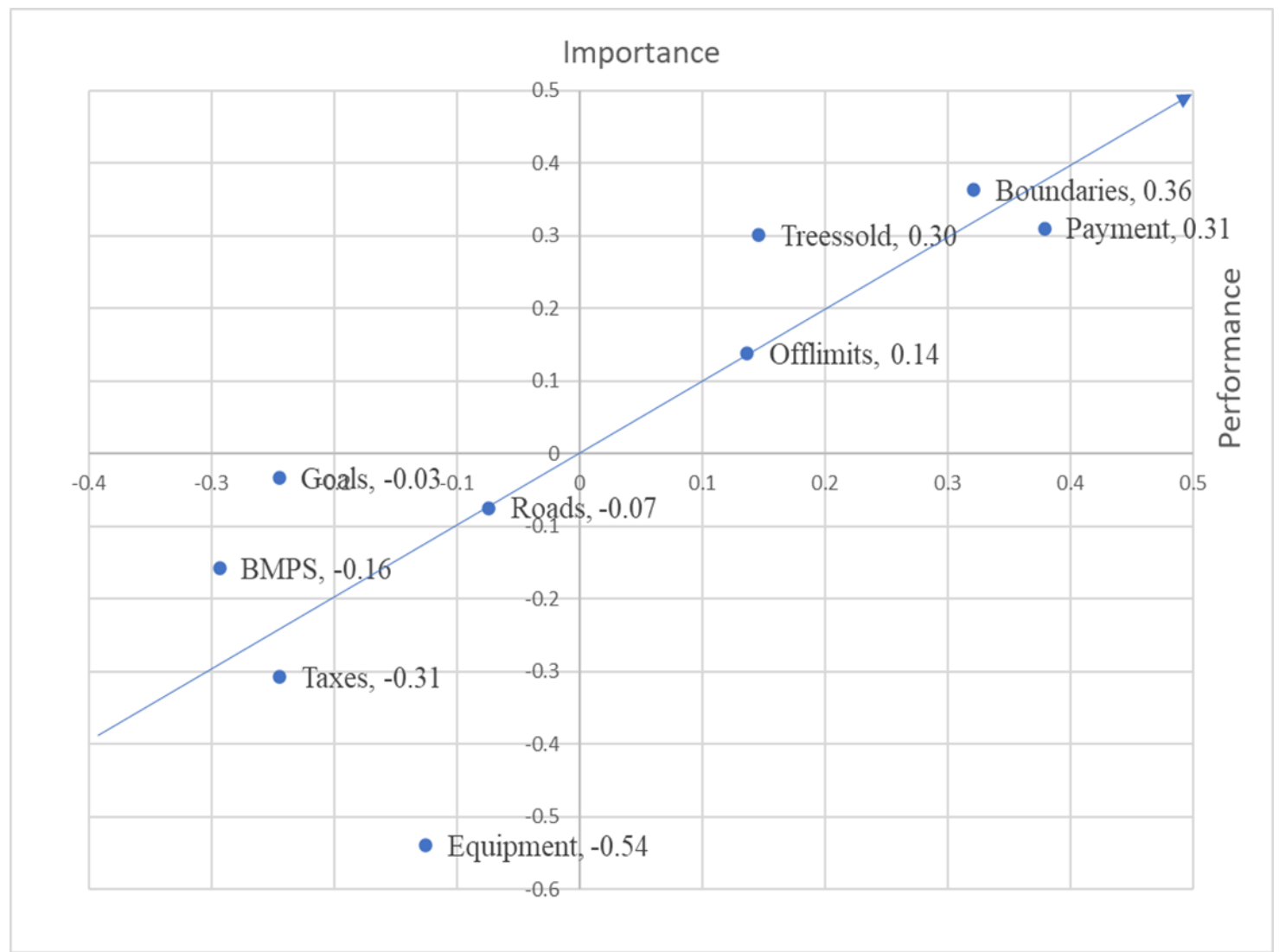

Figure 6. Importance-Performance Analysis of Planning the harvest

Communication attributes that occur during the harvest (Figure 7) show mixed positive and negative results. Attributes found in the "Keep up the good work" quadrant were discussion 
of concerns and being welcomed to the site. However, changing prices, loads and WVDOF visits were rated as "Low Priority". FFOs find that being notified of problems or issues encountered during harvest operations as important but not being accomplished well, hence it is found in the "Concentrate here" quadrant.

Alternatively, welcome to the site, concerns, loads are all found below the iso-rating line suggesting they are being accomplished adequately. Notification of problems, changing prices, WVDOF visits are all found above the iso-rating line suggesting they are not being performed adequately.

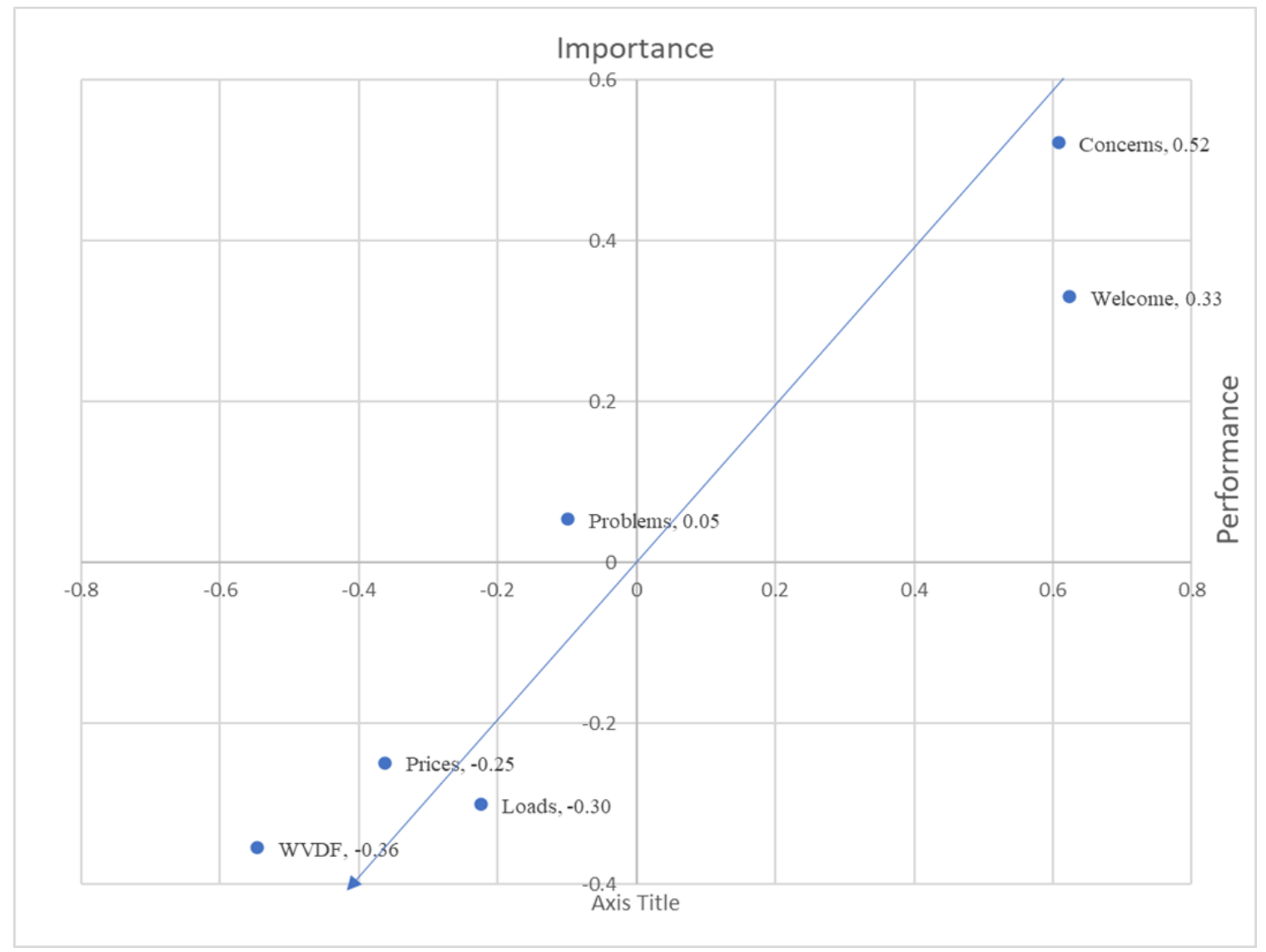

Figure 7. Importance-Performance Analysis of Communication

Harvesting operations attributes (Figure 8) show mostly positive results. Attributes found in the "Keep up the good work" quadrant were, used designated gates and roads, operated in 
designated areas, harvested agreed upon trees, followed the contract are in the "Keep up the good work" quadrant. However, following BMPs, smoothing trails and landing, residual tree condition, filling in ruts and were rated as "Low Priority

Alternatively, the attributes designated gates and roads, operated in designated areas, harvested agreed upon trees are all found below the iso-rating line suggesting they are being accomplished inadequately. Following the contract, following BMPs, smoothing trails and landing, residual tree condition, filling in ruts are all found above the iso-rating line suggesting they are being performed adequately.

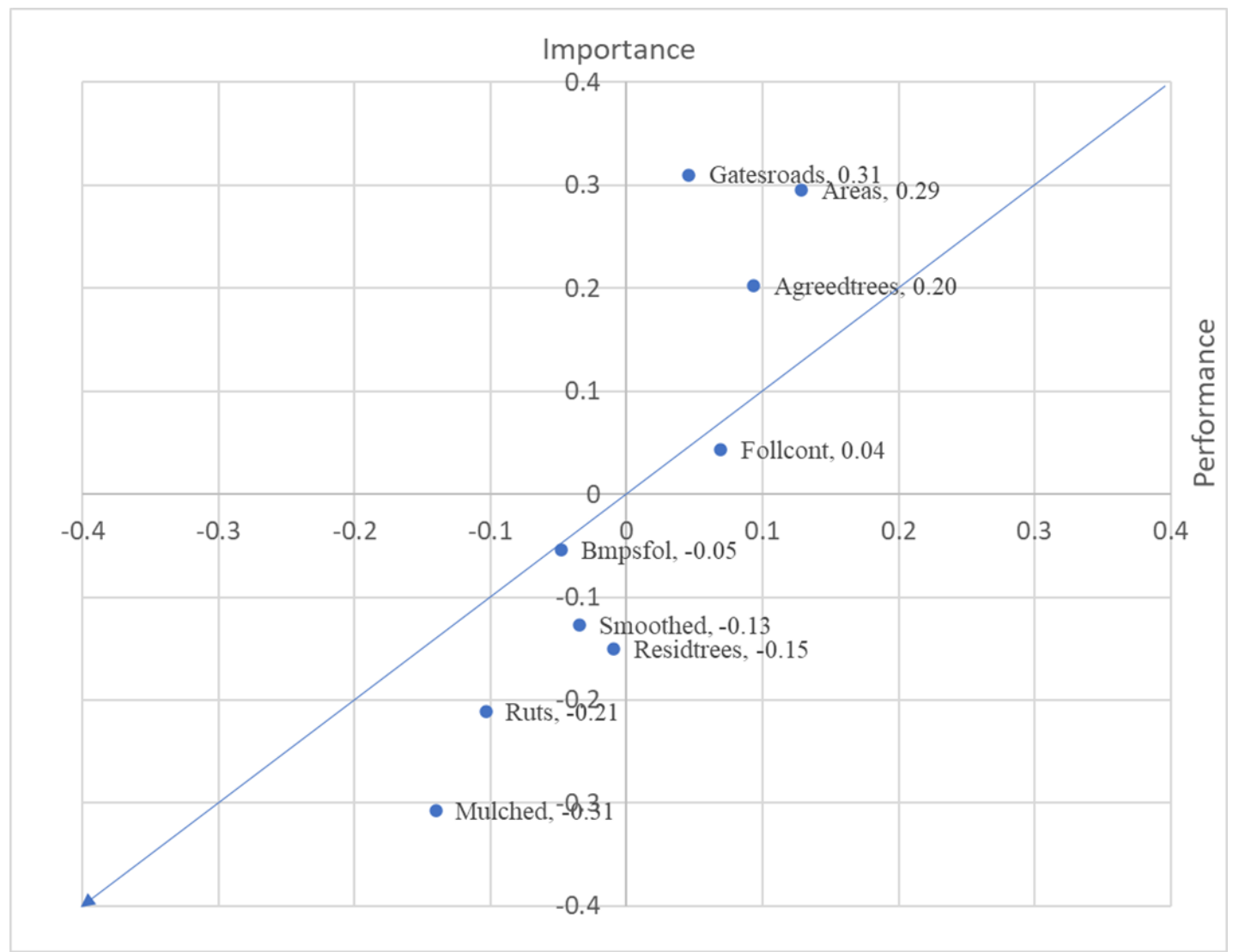

Figure 8. Importance-Performance Analysis of Harvesting Operations 


\section{Univariate logistic regression}

Univariate logistic regression analysis found FFO satisfaction with the harvest was significantly related to attributes of forester involvement, guidance, management knowledge, planning, communication, operations, overall adequacy of planning, communication and harvest operations, and FFO willingness to harvest again (Table 7). FFO's who had a forester were

found be twice as likely to be satisfied than those who did not use a forester. FFO's who received guidance on performing their timber sale were also twice as likely to be satisfied with their timber sale.

FFO's were 13 times more likely to be satisfied with their sale when they adequately planned the sale. Adequate communication with parties involved in the sale with the landowner increased the likelihood that an FFO would be 6.7 times more satisfied with their sale. If the FFO found the adequacy of work done during operations acceptable, they were 16.4 times more likely to be satisfied with their timber sale. If the FFO was satisfied with planning, communication, and operations, they were 3.4 times more likely to be satisfied with their timber harvest. FFOs who planned to harvest again were found to only be $30 \%$ more likely to be satisfied with their timber sale. 
Table 7. Univariate logistic regression of reduced explanatory variables with overall level of satisfaction of timber sale.

\begin{tabular}{lccccc}
\hline Variable & $\mathrm{N}$ & Odds Ratio & $95 \%$ Confidence Limits & $\mathrm{p}$-value \\
\hline residence & 258 & 0.754 & 0.503 & 1.131 & 0.172 \\
Lntotac & 250 & 1.010 & 0.766 & 1.332 & 0.945 \\
firstharv & 252 & 0.781 & 0.414 & 1.475 & 0.446 \\
ownertype & 258 & 1.158 & 0.924 & 1.451 & 0.203 \\
incenttax & 255 & 1.114 & 0.61 & 2.036 & 0.725 \\
plan & 255 & 1.190 & 0.582 & 2.435 & 0.633 \\
guidance & 254 & 2.164 & 1.165 & 4.018 & 0.015 \\
events & 255 & 1.000 & 1.00 & 1.00 & 0.803 \\
Decision & 258 & 1.013 & 0.537 & 1.91 & 0.969 \\
Knew & 258 & 2.095 & 1.118 & 3.926 & 0.021 \\
Discuss & 258 & 1.43 & 0.741 & 2.774 & 0.28 \\
adeqparty & 231 & 1.000 & 1.00 & 1.00 & 0.316 \\
adeqplan & 239 & 13.204 & 3.972 & 43.983 & $<0.000$ \\
adeqcomm & 231 & 6.694 & 3.139 & 14.274 & $<0.000$ \\
adeqoperations & 240 & 16.361 & 5.663 & 47.269 & $<0.000$ \\
adeqindex & 249 & 3.372 & 2.387 & 4.764 & $<0.000$ \\
selltype & 252 & 0.769 & 0.531 & 1.113 & 0.163 \\
Again & 246 & 0.299 & 0.152 & 0.587 & 0.001 \\
Addact & 250 & 0.681 & 0.347 & 1.337 & 0.243 \\
Gender & 256 & 0.902 & 0.426 & 1.912 & 0.789 \\
Age & 256 & 1.243 & 0.99 & 1.562 & 0.061 \\
College & 248 & 0.879 & 0.464 & 1.664 & 0.691 \\
forester & 258 & 2.012 & 0.998 & 4.057 & 0.051 \\
noteyear & 258 & 1.009 & 0.851 & 1.198 & 0.914 \\
\hline
\end{tabular}

\section{Factors affecting satisfaction}

Variables produced from the reduction process (Table 2) were evaluated for their explanatory effects with overall satisfaction with the timber harvest (Table 1) using a logistic regression model. The results show that the adequacy index (adeqindex), and the presence of a forester were significant explanatory variables. The two-covariate model had the strongest values for the goodness-of-fit tests, the deviance $(\mathrm{p}=0.656)$ and Receiver Operating Characteristic $(0.85)$ (Table 8). 
Table 8. Logistic regression of two covariates on landowner's overall satisfaction.

\begin{tabular}{lcc}
\hline Covariate & 2 Covariates p-value & Odds Ratio \\
\hline adeqindex & $<0.000$ & 4.273 \\
forester & 0.026 & 2.530 \\
Goodness of fit & & \\
Deviance (p-value) & 0.656 & \\
Receiver Operating Curve & 0.850 & \\
\hline
\end{tabular}

The adequacy index (adeqindex) that combined the attributes from the planning, communication and operations sections of the questionnaire was statistically related to overall satisfaction. For every additional attribute section deemed adequate by the landowner, the FFO was 4.3 times more likely to state they were satisfied with their timber sale. Inclusion of a forester, regardless of whether they were a procurement, state or consulting forester, led to the FFO being 2.6 times more likely to be satisfied with their timber sale (Table 9).

Table 9. Univariate analysis for variables involved in Best Subsets regression

\begin{tabular}{lccccc}
\hline Variable & $\mathrm{N}$ & Odds Ratio & $95 \%$ Confidence Limits & $\mathrm{p}$-value \\
\hline adeqindex & 246 & 5.123 & 3.153 & 8.325 & $<.0001$ \\
forester & & 2.62 & 1.096 & 6.264 & 0.0304 \\
\hline
\end{tabular}




\section{Chapter 5: Discussion}

Of the 258 responses for overall satisfaction 55 respondents or 21 percent were not satisfied with their timber sale. Furthermore, 12 out of 28 or 43 percent of IPA attributes fell above the iso-rating line. For these attributes, importance exceeded performance which means that the performance of these attributes is not living up to the FFO's expectations. These results show that the attributes of a timber sale can be improved upon, not everyone was satisfied with their timber sale. Regardless of industry, measuring customer satisfaction is an important part of improving quality of work and retaining customers (Cengiz 2010). Satisfaction is considered an indicator of a company's future (Chen et al 2009).

We evaluated many attributes and the only IPA attribute found above the iso-rating line and in the "concentrate here" quadrant was notification of problems encountered during the harvest. This is alarming since the majority of respondents stated that they visited the site daily or weekly. Heiligmann et al. (1986) highly recommends that FFO's communicate with loggers and other forestry professionals. The communication IPA section was a broad section but it does

show that communication is important to the FFO. Notification of problems occurring during the harvest did not ask specifically about the types of problems that could occur. The results of this question suggest that there is a communication disconnect between the FFO and forestry professionals about problems that occur on the site. Further research on the communication attributes of a timber sale could allow forestry professionals an improved understanding of how to communicate and disseminate information to FFOs.

Of all 23 attributes evaluated in this study to describe the attributes of a timber transaction (Table 2), the adequacy index composite variable, and forester participation based on LONIE records, were found to best the best determinants of FFO satisfaction (Table 8). 
The composite variable adeqindex, which contained the performance adequacy of planning, communications, and harvesting operations attributes were found to be significant in the logistic model regardless of the suggested number of covariates. All of the attributes are suggested to be performed by extension literature and the adequacy index shows that if there is an issue with one of the attributes then the respondent's overall satisfaction with their timber sale is likely to suffer. However, this index does not tell us which individual attribute caused the overall satisfaction to suffer. Further research should be done on attributes to determine how to improve adequacy of performance. If an attribute can be improved then the FFO's overall satisfaction with the harvest would possibly improve as well.

Forester involvement was also significant. Most extension publications that give guidance to landowners concerning timber sales (Heiligmann et al. 1986, Bowers 2007, Grotta 2014 Rickenbach 2018) all highly recommend having a forester involved in all phases of the timber sale. Moss et al. (2013) suggests including a consulting forester will benefit the FFO due to the forester representing and protecting the FFO and their land.

Foresters are considered experts and can guide FFOs in planning the harvest, explain to the FFO about specific operations, and help answer questions and concerns that the FFO may have throughout any part of the timber sale process (Rickenbach 2018). Previous research by Maltempie (2017) also corroborates that a forester is important to a positive timber sale. FFOs who failed to hire a forester were likely to have a negative experience with their harvest (Maltempie 2017).

Studies of FFOs have found that if the FFO is a member of a stewardship program they are more likely to have different preconceptions of how to manage their property compared to those who were not a member of a stewardship program (Howle et al 2010). Similarly, is it 
possible that a forester can impact an FFO's preconceptions about harvesting? Future research could attempt to elicit a response of how a forester's involvement interacts with the adequacy of the attributes of a timber sale.

Demographic variables gender, age, and education level were all found to be insignificant in this study. Age, education level and gender contradict studies by Joshi and Arano (2009) and Sauliner et al. (2017) who found that age and education can be a predictor of willingness to harvest or manage their property. However, these did attributes did not seem impact the respondent's overall satisfaction with their harvest in this study. This suggests that willingness to harvest may not impact this group of respondents due to them possibly having attributes similar to FFOs who are willing to harvest. Many of the respondents mentioned that they lease their properties for agricultural uses, or just under half of the respondents were using agricultural tax incentives. Other studies have found that farmers are more likely to harvest or manage their property compared to others (Joshi and Arano 2009).

The composite variable decision was found to be insignificant. McGill et al. (2006) had found that the majority of FFOs harvested for income or because the stand was mature. However, in this study, the reason to harvest did not seem to impact overall satisfaction. Similarly, most variables representing the background of the FFO such as where the FFO resides, how many acres the FFO owns, type of ownership, and use of incentive taxation ere all found to be insignificant. Joshi and Arano (2009) found that FFOs who had management plans were likely to be engaged in management activities on their properties. However, FFO management plans did not impact overall satisfaction with a timber sale for this group of respondents.

The method used to sell timber was also insignificant. Extension literature overwhelmingly recommends selling timber by soliciting sealed bids (Heiligmann et al. 1986, 
Bowers 2007, Grotta 2014 Rickenbach 2018). The literature suggests that there are advantages to using sealed bids for selling timber. However, the type of timber sale did not impact overall satisfaction for this group of West Virginia landowners. Other research by Kittredge et al. (1996) found that attributes such as tract size, distance and quality of timber can impact the company's interest in placing a bid. Logging companies can be diverse in structure, size, and ability (Moss et al. 2003). Maltempie 2017 found that interviewees with small logging companies did not trust their logging company. Sale type in this study was broadly worded sand only asked about the type of the sale, it did not specify information related to the structure of the logging company the FFO used.

This research shows that FFO views of satisfaction are as complex as the timber sale itself. The measure of overall satisfaction was a composite response variable, suggesting that all attributes representing satisfaction were related and impacted by what occurred during the sale. FFOs in this study are not just interested in the amount of income received from the harvest but also other aspects such as their contract, property goals, information available and the condition of their property. The adequacy index's impact on overall satisfaction is important, but it is broad and shows that each attribute's adequacy can impact overall satisfaction. A more refined view of each individual attribute may shed more light on how and where professionals and landowners can work together for even greater satisfaction in timber transactions. 


\section{Literature Cited}

Abalo, J., Varela, J., \& Manzano, V. 2007. Importance values for Importance-Performance Analysis: A formula for spreading out values derived from preference rankings. Journal of Business Research, 60(2), 115-121.

Adams, D. M. 2006. Estimated timber harvest by US region and ownership, 1950-2002 (Vol. 659). US Department of Agriculture, Forest Service, Pacific Northwest Research Station.

Anderson, S. W., Baggett, L. S., \& Widener, S. K. 2009. The impact of service operations failures on customer satisfaction: evidence on how failures and their source affect what matters to customers. Manufacturing \& Service Operations Management, 11(1), 52-69.

Barden, C. J., Jones, S. B., \& Biles, L. E. 1996. Extension forestry education: Reaching the people who make decisions. Journal of Forestry, 94(3), 31-35.

Berry, J., Brewer, G. D., Gordon, J. C., \& Patton, D. R. 1998. Closing the gap between ecosystem management and ecosystem research. Policy Sciences, 55-80.

Best, Constance, Wayburn, A., Laurie. 2001. America's Private Forests. Washington D.C.: Island Press

Bowers, S., \& Punches, J. 2007. Selling timber and logs.

https://ir.library.oregonstate.edu/concern/administrative_report_or_publications/np193948x

Butler, B. J., \& Leatherberry, E. C. 2004. America's family forest owners. Journal of Forestry, 102(7), 4-14.

Butler, B. J. (2008). Family forest owners of the United States, 2006. Gen. Tech. Rep. NRS-27. Newtown Square, PA: US Department of Agriculture, Forest Service, Northern Research Station. 72 p., 27.

Butler, B. J., Ma, Z., Kittredge, D. B., \& Catanzaro, P. 2010. Social versus biophysical availability of wood in the northern United States. Northern Journal of Applied Forestry, 27(4), 151-159.

Butler, B. J., \& Ma, Z. 2011. Family forest owner trends in the Northern United States. Northern Journal of Applied Forestry, 28(1), 13-18.

Butler, B. J., Markowski-Lindsay, M., Snyder, S., Catanzaro, P., Kittredge, D. B., Andrejczyk, K., ... \& Tadle, D. 2014. Effectiveness of landowner assistance activities: An examination of the USDA Forest Service's Forest Stewardship Program. Journal of Forestry, 112(2), 187-197.

Butler, J., Brett, Hewes, H., Jaketon, Dickinson, J., Brenton, Andrejczyk, Kyle, Butler, M., Sarah, Markowski-Lindsay, Marla. 2016. Family Forest Ownership of the United States, 2013: 
Findings from the USDA Forest Service's National Woodland Owner Survey. Journal of Forestry 114(6): 638-647

Cengiz, E. 2010. Measuring customer satisfaction: must or not. Journal of naval science and engineering, 6(2), 76-88.

Chaudhary, Kumar, Anil, Warner, A., Laura. 2016. Identifying Gaps between Importance and Satisfaction to Identify Extension Clients' Needs.

Gabbert, C. C., Gazal, K., \& McNeel, J. 2020. Economic Contributions of West Virginia's Forest Products Industry Over Time: A Look at 2006, 2010, 2015, and 2017 Data. Forest Products

Journal, 70(2), 200-212.

Chan, Y., \& Walmsley, R. P. 1997. Learning and understanding the Kruskal-Wallis one-way analysis-of-variance-by-ranks test for differences among three or more independent groups. Physical therapy, 77(12), 1755-1761.

Chen, Xiaoling, Martin, Melissa, Merchant, Kenneth. 2009. Customer Satisfaction. Financial Management 34-35

Davis, M. L. S., \& Fly, J. M. 2010. Do you hear what I hear: Better understanding how forest management is conceptualized and practiced by private forest landowners. Journal of Forestry, 108(7), 321-328.

Davis, M. L. S., Asah, S. T., \& Fly, J. M. 2015. Family forest owners' forest management understandings: Identifying opportunities and audiences for effective outreach and education. Forest Science, 61(1), 105-113.

Deng, J., \& Pierskalla, C. D. 2018. Linking Importance-Performance Analysis, Satisfaction, and Loyalty: A Study of Savannah, GA. Sustainability, 10(3), 704.

Dillman, Don. Mail and Internet Surveys the Tailored Design Method. John Wiley \& Sons, Inc, 2000.

Ennew, C. T., Reed, G. V., \& Binks, M. R. 1993. Importance-performance analysis and the measurement of service quality. European journal of marketing, 27(2), 59-70.

Favada, I. M., Kuuluvainen, J., \& Uusivuori, J. 2007. Consistent estimation of long-run nonindustrial private forest owner timber supply using micro data. Canadian journal of forest research, 37(8), 1485-1494.

Forbes, S. J. 2008. The effect of service quality and expectations on customer complaints. The Journal of industrial economics, 56(1), 190-213. 
Greene, J. L., Kilgore, M. A., Jacobson, M. G., Daniels, S. E., \& Straka, T. J. 2007. Existing and potential incentives for practicing sustainable forestry on non-industrial private forest lands. In: Siry, J., ed. Proceedings of the 2006 Southern Forest Economics Workshop. 174-187. (pp. 174-187).

Grotta, A. T., Bondi, M. C., \& Landgren, C. G. 2014. Management planning for woodland owners: why and how.

Grushecky, S. T., Wiedenbeck, J., \& Hassler, C. C. 2012. Examination of roundwood utilization rates in West Virginia. Forest Products Journal, 62(7-8), 507-515.

Hernández-Espallardo, M., Arcas-Lario, N., \& Marcos-Matás, G. 2013. Farmers' satisfaction and intention to continue membership in agricultural marketing co-operatives: neoclassical versus transaction cost considerations. European Review of Agricultural Economics, 40(2), 239-260.

Hoover, W. L., \& Seifert, J. R.2002. Tips on How to Get the Most from Your Timber Harvest. https://www.extension.purdue.edu/extmedia/fnr/fnr-138.pdf

Howle, M. B., Straka, T. J., \& Nespeca, M. C. 2010. Family forest owners' perceptions on chemical methods for invasive species control. Invasive Plant Science and Management, 3(3), 253-261.

Heiligmann, R. B., Bratkovitch, S. M., \& Koelling, M. 1986. Marketing Timber from the Private Woodland.

Israel, G. D. 1992. Determining sample size.

https://www.tarleton.edu/academicassessment/documents/Samplesize.pdf

Jolliffe, I. T., \& Cadima, J. 2016. Principal component analysis: a review and recent developments. Philosophical Transactions of the Royal Society A: Mathematical, Physical and Engineering Sciences, 374(2065), 20150202.

Joshi, S., \& Arano, K. G. 2009. Determinants of private forest management decisions: a study on West Virginia NIPF landowners. Forest Policy and Economics, 11(2), 118-125.

Joy,S., Mark. 2003. American Expansionism, 1781-1860 a Manifest Destiny. London. Pearson Education Limited

Kendra, A., \& Hull, R. B. 2005. Motivations and behaviors of new forest owners in Virginia. Forest Science, 51(2), 142-154.

Kittredge Jr, D. B., Mauri, M. J., \& McGuire, E. J. 1996. Decreasing woodlot size and the future of timber sales in Massachusetts: when is an operation too small? Northern Journal of Applied Forestry, 13(2), 96-101. 
Kittredge, D. B. 2004. Extension/outreach implications for America's family forest owners. Journal of Forestry, 102(7), 15-18.

Korhonen, K., Hujala, T., \& Kurttila, M. 2012. Reaching forest owners through their social networks in timber sales. Scandinavian journal of forest research, 27(1), 88-99.

Krejcie, R. V., \& Morgan, D. W. 1970. Determining sample size for research activities. Educational and psychological measurement, 30(3), 607-610.

Lee, H. S. 2015. Measurement of visitors' satisfaction with public zoos in Korea using importance-performance analysis. Tourism management, 47, 251-260.

Ma, Z., \& Kittredge, D. B. 2011. How family forest owners consider timber harvesting, land sale, and conservation easement decisions: Insights from Massachusetts, USA. International Journal of Forestry Research, 2011.

Maltempie, Adam, "A Qualitative Study of Family Forest Owners' Experiences with Timber Transactions" 2017. Graduate Theses, Dissertations, and Problem Reports. 6151. https://researchrepository.wvu.edu/etd/6151

Martilla, J. A., \& James, J. C. 1977. Importance-performance analysis. Journal of marketing, 41(1), 77-79.

Matsunaga, M. 2010. How to Factor-Analyze Your Data Right: Do's, Don'ts, and HowTo's. International journal of psychological research, 3(1), 97-110.

McGill, D. W., Magill, D. J., Kochenderfer, J., Ford, W. M., \& Schuler, T. 2006. Information transfer during the timber transaction period in West Virginia. USA. In In: Proceedings 7th extension working party symposium, communication strategies for multiple partner involvement in forestry extension, IUFRO working party 6.06. 03 extension, Orvieto, Italy, September 2004..

McGill, D. W., Pierskalla, C. D., Jennings, B. M., Grushecky, S. T., \& Lilly, D. 2006. Landowner satisfaction with timber harvesting on West Virginia forest stewardship program properties. Northern Journal of Applied Forestry, 23(1), 6-10.

McGill, D. W., Grushecky, S. T., Moss, S., Pierskalla, C., \& Schuler, A. 2008. Landowner willingness to engage in long-term timber leases in West Virginia, USA. Small-scale Forestry, 7(2), 105-116.

Mehmood, S. R., \& Zhang, D. 2001. Forest parcelization in the United States: a study of contributing factors. Journal of Forestry, 99(4), 30-34.

Montgomery, R., Dennis, J. M., \& Ganesh, N. 2016. Response rate calculation methodology for recruitment of a two-phase probability-based panel: the case of AmeriSpeak. University of Chicago National Opinion Research Center White Paper. 
Morin, R. S., Domke, G. M., \& Walters, B. F. 2017. Forests of West Virginia, 2016. Resource Update FS-123. Newtown Square, PA: US Department of Agriculture, Forest Service, Northern Research Station. 4 p., 123, 1-4.

Moss, S. A., \& Heitzman, E. 2013. The economic impact of timber harvesting practices on NIPF properties in West Virginia.

Moss, S. A., \& Heitzman, E. 2013. Impact of professional foresters on timber harvests on West Virginia nonindustrial private forests.

Nelson, M. D., Liknes, G. C., \& Butler, B. J. (2010). Map of forest ownership in the conterminous United States]. Res. Map NRS-2. Newtown Square, PA: US Department of Agriculture, Forest Service, Northern Research Station., 2, 1-2.

O'Connor, B. P. 2000. SPSS and SAS programs for determining the number of components using parallel analysis and Velicer's MAP test. Behavior Research Methods, Instruments, and Computers, 32(3), 396-402.

Oh, H. 2001. Revisiting importance-performance analysis. Tourism management, 22(6), 617627.

Oswalt, S. N., \& Smith, W. B. (Eds.). 2014. US forest resource facts and historical trends. United States Department of Agriculture, Forest Service.

Parasuraman, A., Zeithaml, V. A., \& Berry, L. L. 1988. Servqual: A multiple-item scale for measuring consumer perc. Journal of retailing, 64(1), 12.

Poschman, H. 2014. Public Lands in the West. http://knowledgecenter.csg.org/kc/system/files/Public_0.pdf

Renner, M., \& Taylor-Powell, E. 2003. Analyzing qualitative data. Programme Development \& Evaluation, University of Wisconsin-Extension Cooperative Extension, 1-10.

Rickenbach, Mark, Finely, Mike, Klase, William, Tiles, Kris. 2018. Conducting a Successful Timber Sale a Primer for Landowners. University of Wisconsin Extension Service.

Salmon, O., Brunson, M., \& Kuhns, M. 2006. Benefit-based audience segmentation: A tool for identifying nonindustrial private forest (NIPF) owner education needs. Journal of Forestry, 104(8), 419-425.

Saulnier, W. J., Bolding, M. C., Barrett, S. M., \& Prisley, S. P. 2017. Characteristics of Virginia's private forest landowners and their attitudes toward harvesting. Forest Products Journal, 67(1-2), 69-80.

Snyder, S. A., Butler, B. J., \& Markowski-Lindsay, M. 2019. Small-Area Family Forest Ownerships in the USA. Small-scale Forestry, 18(1), 127-147. 
Spong, B. 2013. The West Virginia Logging Operation Notification, Inspection, and Enforcement System. In Council on Forest Engineering Annual Meeting, Forest Operations for a Changing Landscape. Missoula, Montana USA

Sudman, S., \& Bradburn, N. M. 1973. Effects of time and memory factors on response in surveys. Journal of the American Statistical Association, 68(344), 805-815.

Walkingstick, T., Voth, D. E., Williams, R. A., Earl, J., \& Hitt, C. P. 2001. Landowners of Arkansas. In Proceedings of the Symposium on Arkansas Forests: A Conference on the Results of the Recent Forest Survey of Arkansas, 1997 May 30-31, North Little Rock, AR (Vol. 41, p. 85). US Department of Agriculture, Forest Service, Southern Research Station.

Weiner, B. 2000. Attributional thoughts about consumer behavior. Journal of Consumer research, 27(3), 382-387.

Wiersema, W. H. 2004. Is it time to sell your business?. Electrical Apparatus, 57(1), 40-40.

Wiseman, F. 2003. On the reporting of response rates in Extension research. Journal of Extension, 41(3), 1-5.

Zhang, Y., Zhang, D., \& Schelhas, J. 2005. Small-scale non-industrial private forest ownership in the United States: rationale and implications for forest management. Silva Fennica, Vol. 39 (3): 443-454. 
Appendix A: Name and Definition of Variables used.

Section 1 Property Management

\begin{tabular}{ll}
\hline Variable & Definition \\
\hline residence & FFO residence status. 1=Yes, 2=No, 3=I plan to in the future, \\
& 4=I plan to sell the property after logging \\
totac & Total acres owned. \\
harvacres & Total harvested acres. \\
numharvs & Total number of harvests completed. \\
lease & Lease of FFO property. \\
& $1=$ No, 2=Yes, leased for the purpose of \\
ownertype & FFO description of property ownership. \\
& 1=Individual, 2=Joint with Spouse, 3=Corporation/business \\
& partnership, 4= Family, 5=Multiple ownership, 6=Trust or \\
& Estate, 7=other \\
taxtype & FFO taxation. 1=Managed Timberland, 2=Farmland, 3=I \\
& don't know, 4=other \\
writtenplan & FFO property management plan. 1=Yes, Forestry Plan, \\
& $2=$ Yes Farm plan, 3=No, 4=I don't know
\end{tabular}


Section 2: Deciding to sell your timber

\begin{tabular}{|c|c|}
\hline Variable & Definition \\
\hline guidance & $\begin{array}{l}\text { FFO use of information and guidance. } 1=\text { No, } 2=\text { Yes from } \\
\text { where }\end{array}$ \\
\hline events & $\begin{array}{l}\text { FFO decision to sell timber. } 1=\mathrm{I} \text { was asked to sell timber, } \\
2=\mathrm{I} \text { first decided to sell timber, } 3=\text { other }\end{array}$ \\
\hline \multicolumn{2}{|l|}{ Decision to harvest } \\
\hline decneigh & $\begin{array}{l}\text { Neighbors were selling timber. 1=Strongly Disagree, } \\
\text { 4=Strongly Agree }\end{array}$ \\
\hline decincome & $\begin{array}{l}\text { FFO needed income. } 1=\text { Strongly Disagree, } 4=\text { Strongly } \\
\text { Agree }\end{array}$ \\
\hline decstand & Stand improvement $1=$ Strongly Disagree, $4=$ Strongly Agree \\
\hline deaccess & $\begin{array}{l}\text { Improve access or change land use. } 1=\text { Strongly Disagree, } \\
4=\text { Strongly Agree }\end{array}$ \\
\hline decother & $\begin{array}{l}\text { Other reasons. Open ended and 1=Strongly Disagree, } \\
\text { 4=Strongly Agree }\end{array}$ \\
\hline meon & FFO's main concerns with selling timber. \\
\hline \multicolumn{2}{|l|}{ Management knowledge } \\
\hline beferosion & $\begin{array}{l}\text { FFO knowledge of erosion. 1=Strongly Disagree, } \\
\text { 4=Strongly Agree }\end{array}$ \\
\hline befinvasive & $\begin{array}{l}\text { FFO knowledge of invasive species. 1=Strongly Disagree, } \\
\text { 4=Strongly Agree }\end{array}$ \\
\hline befcontract & $\begin{array}{l}\text { FFO knowledge of logging contracts. 1=Strongly Disagree, } \\
\text { 4=Strongly Agree }\end{array}$ \\
\hline befgoals & $\begin{array}{l}\text { FFO established goals for property. 1=Strongly Disagree, } \\
\text { 4=Strongly Agree }\end{array}$ \\
\hline befneigh & $\begin{array}{l}\text { FFO discussed selling timber with neighbors. } 1=\text { Strongly } \\
\text { Disagree, } 4=\text { Strongly Agree }\end{array}$ \\
\hline beffamily & $\begin{array}{l}\text { FFO discussed selling timber with family. 1=Strongly } \\
\text { Disagree, } 4=\text { Strongly Agree }\end{array}$ \\
\hline befliability & $\begin{array}{l}\text { FFO understood liabilities associated with logging. } \\
1=\text { Strongly Disagree, } 4=\text { Strongly Agree }\end{array}$ \\
\hline beflookduring & $\begin{array}{l}\text { FFO preparation for look of property during harvest. } \\
\text { 1=Strongly Disagree, } 4=\text { Strongly Agree }\end{array}$ \\
\hline
\end{tabular}


Section 3: Planning the timber sale

\begin{tabular}{|c|c|}
\hline Variable & Definition \\
\hline \multicolumn{2}{|l|}{ FFO Preparation } \\
\hline beflookduring & $\begin{array}{l}\text { FFO preparation for look of property during harvest. } 1=\text { Strongly } \\
\text { Disagree, } 4=\text { Strongly Agree }\end{array}$ \\
\hline beflookafter & $\begin{array}{l}\text { FFO preparation for looks of property after harvest. 1=Strongly } \\
\text { Disagree, } 4=\text { Strongly Agree }\end{array}$ \\
\hline befincome & $\begin{array}{l}\text { FFO preparation for income received from harvest. 1=Strongly } \\
\text { Disagree, } 4=\text { Strongly Agree }\end{array}$ \\
\hline befexpect & $\begin{array}{l}\text { FFO knew what to expect from the harvest. 1=Strongly Disagree, } \\
4=\text { Strongly Agree }\end{array}$ \\
\hline \multicolumn{2}{|c|}{ Parties involved in the sale } \\
\hline ICforester/IPforester & $\begin{array}{l}\text { Importance and Performance of consulting forester. } 1=\text { Not } \\
\text { Important-4=Essential, } 1=\text { Poor- } 4=\text { Excellent }\end{array}$ \\
\hline IPforester/PPforester & $\begin{array}{l}\text { Importance and Performance of procurement forester. } 1=\text { Not } \\
\text { Important- } 4=\text { Essential, } 1=\text { Poor- } 4=\text { Excellent }\end{array}$ \\
\hline ISforester/PSforester & $\begin{array}{l}\text { Importance and Performance of state forester. 1=Not Important- } \\
\text { 4=Essential, 1=Poor-4=Excellent }\end{array}$ \\
\hline Ilogger/Plogger & $\begin{array}{l}\text { Importance and Performance of loggers. 1=Not Important- } \\
\text { 4=Essential, 1=Poor-4=Excellent }\end{array}$ \\
\hline Iotherparty/Potherparty & $\begin{array}{l}\text { Importance and performance of other parties that may have been } \\
\text { part of the sale. } 1=\text { Not Important-4=Essential, } 1=\text { Poor- } 4=\text { Excellent }\end{array}$ \\
\hline \multicolumn{2}{|l|}{ Harvest planning } \\
\hline Itreessold/Ptreessold & $\begin{array}{l}\text { Determined trees to be sold. } 1=\text { Not Important- } 4=\text { Essential, } 1=\text { Poor- } \\
4=\text { Excellent }\end{array}$ \\
\hline Iboundaries/Pboudaries & $\begin{array}{l}\text { Determined property and harvest boundaries. 1=Not Important- } \\
\text { 4=Essential, 1=Poor-4=Excellent }\end{array}$ \\
\hline Iofflimits/Pofflimits & $\begin{array}{l}\text { Marked areas that were off limits to use. } 1=\text { Not Important- } \\
4=\text { Essential, } 1=\text { Poor- } 4=\text { Excellent }\end{array}$ \\
\hline Iequipment/Pequipment & $\begin{array}{l}\text { Determined size and type of equipment to use in the harvest. } 1=\text { Not } \\
\text { Important- } 4=\text { Essential, } 1=\text { Poor- } 4=\text { Excellent }\end{array}$ \\
\hline Iroads/Proads & $\begin{array}{l}\text { Determined road placement. } 1=\text { Not Important- } 4=\text { Essential, } 1=\text { Poor- } \\
4=\text { Excellent }\end{array}$ \\
\hline Igoals/Pgoals & $\begin{array}{l}\text { Determined property goals. } 1=\text { Not Important-4=Essential, } 1=\text { Poor- } \\
4=\text { Excellent }\end{array}$ \\
\hline Itaxes/Ptaxes & $\begin{array}{l}\text { Determined how taxes would be dealt with. 1=Not Important- } \\
4=\text { Essential, } 1=\text { Poor-4=Excellent }\end{array}$ \\
\hline Ibmps/Pbmps & $\begin{array}{l}\text { Discussed BMPs. 1=Not Important-4=Essential, 1=Poor- } \\
\text { 4=Excellent }\end{array}$ \\
\hline Ipayment/Ppayment & $\begin{array}{l}\text { Discussed method of payment. 1=Not Important-4=Essential, } \\
1=\text { Poor- } 4=\text { Excellent }\end{array}$ \\
\hline conttype & $\begin{array}{l}\text { Type of contract used. } 1=\text { Sealed bid, } 2=\text { Negotiated sale, } 3=\text { Paid on } \\
\text { shares, } 4=\text { other }\end{array}$ \\
\hline
\end{tabular}


Section 3 The logging operations $(I / P=$ importance/performance $)$,

\begin{tabular}{ll} 
Variable & Definition \\
\hline visits & Number of times the FFO visited the site. \\
FFo Communication & FFO was welcomed to the site. 1=Not Important- \\
Iconcerns/Pconcerns & $\begin{array}{l}\text { 4=Essential, 1=Never Occurred-4=Always Occurred } \\
\text { FFO concerns and questions were answered. 1=Not } \\
\text { Important-4=Essential, 1=Never Occurred-4=Always } \\
\text { Occurred }\end{array}$ \\
Iloads/Ploads & $\begin{array}{l}\text { FFO was notified of loads leaving site. 1=Not Important- } \\
\text { 4=Essential, 1=Never Occurred-4=Always Occurred }\end{array}$ \\
Iproblems/Pproblems & $\begin{array}{l}\text { FFO was notified of problems that occurred. 1=Not } \\
\text { Important-4=Essential, 1=Never Occurred-4=Always }\end{array}$ \\
Iwvdof/Pwvdof & $\begin{array}{l}\text { Occurred } \\
\text { FFO was notified of State Forester visits or findings. 1=Not }\end{array}$ \\
Important-4=Essential, 1=Never Occurred-4=Always \\
Occurred
\end{tabular}


Section 5 After the logging was completed

\begin{tabular}{|c|c|}
\hline Variable & Definition \\
\hline infoS & $\begin{array}{l}\text { Who or what was the main source of information during the } \\
\text { sale and was it accurate? }\end{array}$ \\
\hline satrevrec & $\begin{array}{l}\text { Satisfied with the amount of revenue. } 1=\text { Very Dissatisfied- } \\
\text { 4=Very Satisfied }\end{array}$ \\
\hline sattimbersale & $\begin{array}{l}\text { Satisfied with the entirety of the timber sale. } 1=\text { Very } \\
\text { Dissatisfied-4=Very Satisfied }\end{array}$ \\
\hline satcontract & $\begin{array}{l}\text { Satisfied with contract. 1=Very Dissatisfied-4=Very } \\
\text { Satisfied }\end{array}$ \\
\hline satgoals & $\begin{array}{l}\text { Satisfied with how well goals were accomplished. 1=Very } \\
\text { Dissatisfied-4=Very Satisfied }\end{array}$ \\
\hline satcond & $\begin{array}{l}\text { Satisfied with the condition of the property after harvest. } \\
1=\text { Very Dissatisfied-4=Very Satisfied }\end{array}$ \\
\hline satharvprac & $\begin{array}{l}\text { Satisfied with information received about harvesting } \\
\text { practices. 1=Very Dissatisfied-4=Very Satisfied }\end{array}$ \\
\hline addact & $\begin{array}{l}\text { Additional work had to be performed after the sale. } 1=\mathrm{No} \text {, } \\
2=\text { Yes, what was done? }\end{array}$ \\
\hline best & Positive aspects of sale. \\
\hline worst & negative aspects of sale \\
\hline again & Willingness to harvest again. $1=$ Yes, $2=$ No, why not? \\
\hline changes & $\begin{array}{l}\text { Issues encountered during the harvest and how they would } \\
\text { be corrected by the FFO. }\end{array}$ \\
\hline concerns & Financial concerns \\
\hline
\end{tabular}


Part 6 Demographics

\begin{tabular}{ll}
\hline Variable & Definition \\
\hline gender & Gender of the respondent. 1=Male, 2=Female \\
age & Age of the respondent in years. $1=18-24,2=25-34,3=35-44$, \\
& $4=45-54,5=55-64,6=65-74,7=75-84,8=84$ or greater \\
grossincome & Annual household income of the respondent. $1=15,000-$ \\
& $24,999,2=25,000-49,999,3=50,000-74,000,4=75,000-$ \\
& $99,000,5=100,000-199,999,6=200,000$ or more \\
educ & Education level of the respondents $1=$ Some High School, \\
& 2=High School, 3=Associate's degree, 4=Bachelor's \\
& Degree, $5=$ Master's Degree, 6=Ph.D. or Higher, 7=Trade \\
& School, 8=Prefer not to say \\
\hline
\end{tabular}




\section{Appendix B: Questionnaire Cover Letter.}

\section{WestVirginiaUniversity.}

DAMS COLLEGE OF AGRICULTURE, NATURAL RESOURCES AND DESIGN EXIENSION SERVICE - AGRICULTURE AND NATURAL RESOURCES

September 27,2019

Dear West Virginia Woodland Owner:

We are writing to ask for your help in a research project that is exploring the question "What makes a timber sale successful?" We are contacting woodland owners in West Virginia who have recently harvested timber to ask what they have learned in the process of selling timber. The primary goal of this research is to share findings with others to achieve improved environmental, economic, and social benefits in future West Virginia timber sales.

Please consider contributing your experience and knowledge to this research effort by taking a few minutes to fill out this survey. Your participation in this survey is voluntary and you can quit at any time without penalty. You do not have to answer all the questions, but any information you provide will contribute to the project's success. You must be over 18 years of age to participate. If you do not wish to participate, please let us know by returning the enclosed questionnaire, blank or with a note in the prepaid envelope provided.

Information you provide is confidential; only summaries will be reported in which a single individual's answers cannot be identified. When you return your completed questionnaire, your name will be deleted from the mailing list and will not be connected to your answers in any way. Acknowledgment of this study is on file with West Virginia University's Institutional Review Board.

If you have any further questions, please feel free to contact us at the phone numbers below. Thank you in advance for your participation. It is with your generous help that our research can be successful.

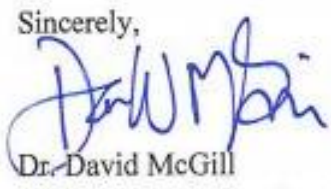

Professor/Extension Specialist Forestry

(304) 293-5930

dmcgill@wvu,edu

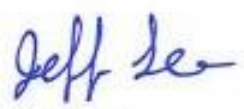

Jeffrey Lee

Graduate Research Assistant

(304) $992-4091$

jlee20@mix.wvu.edu

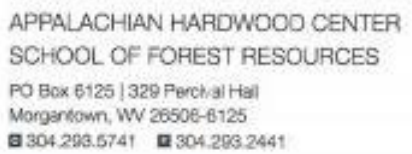


Appendix C: Survey Instrument.

\title{
West Virginia Timber Sale Survey
}

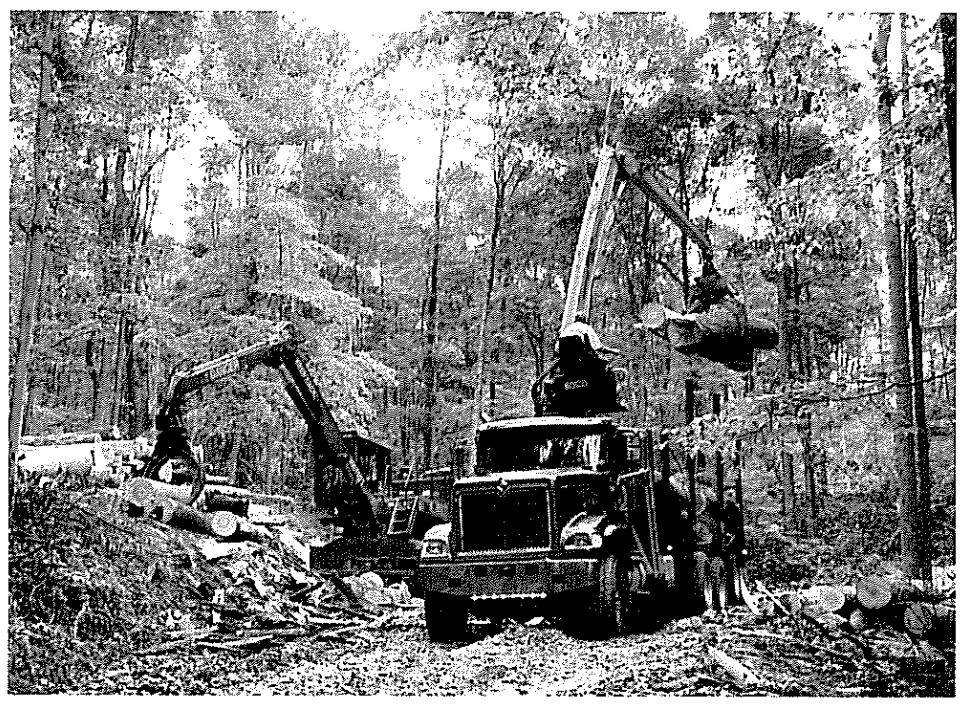

\section{February 2020. Research in collaboration with:}
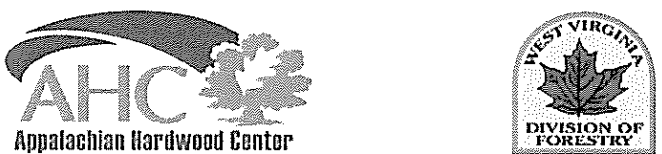

West WirginiaUniversity
EXtension service

\begin{abstract}
About This Survey back in the enclosed, pre-posted envelope. contact:

Dr. Dave McGill, Primary Investigator

Professor/Extension Specialist

dmcgill@wvu.edu

304-293-5930
\end{abstract}

The goal of this survey is to ask landowners what they have learned about timber sales after having had one. Timber sales can be very successful, catastrophic, or everything in between. With your help, we may improve the environmental, economic, and social benefits of West Virginia timber sales.

Please fill the survey out even if you have just started a timber sale on your property. Your participation is voluntary, and you have the right to refrain from answering any question. Your answers will be kept confidential. Please make sure any changed answers are either clearly erased or crossed out, then mail it

Thank you for your assistance with this important research! If you have any questions, please

Jeff Lee

Graduate Research Assistant jlee20@mix.wvu.edu

$\mathrm{j} 2228$ 


\section{START HERE:}

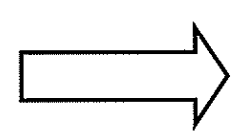

Please read carefully the following items and check all that apply.

I have already completed my timber sale.

$\mathrm{I}$ am in the process of completing my timber sale.

I am in the process of planning my timber sale.

I would like to receive a copy of the results from this survey

I prefer not to participate in this survey (please return blank questionnaire).

Part 1. Management of your property

1. Please indicate your residence status for the property you have most recently harvested.

$\square$ Yes $\square$ No $\square$ I plan to in the future. $\square$ I plan to sell my property after logging.

2. My property is total acres and I harvested acres during the most recent sale.

3. How many timber harvests have you ever completed?

4. Do you lease or let others use any part of this property?

No $\square$ Yes, leased for the purpose of:

5. Which category below best describes your ownership? (check only one)

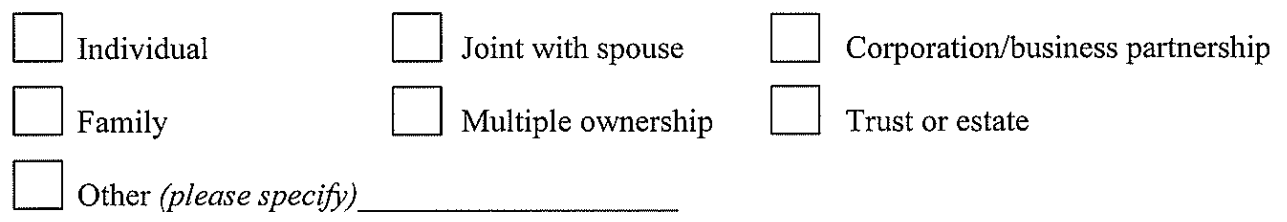

6. How is your property taxed? (check all that apply)

$\square$ Managed Timberland $\square$ Farmland $\square$ I don't know $\square$ Other:

7. Do you currently have a written plan for your property?

$\square$ Yes, Forestry Plan $\square$ Yes, Farm Plan $\square$ No $\square$ I don't know

\section{Part 2. Deciding to sell timber}

8. Prior to deciding to sell timber, did you receive guidance or information on the best way to harvest timber?

No $\square$ Yes If $\underline{Y e s}$, from where?

9. What was the sequence of events when you were deciding to sell your timber? (Please select one)

$\square$ I was asked to sell my timber by a logging company or timber buyer, then decided to sell.

I first decided to sell my timber, then I contacted a professional (e.g., logger, forester).

Other: 
10. Please read the following statements and mark how strongly you agree or disagree.

\begin{tabular}{|c|c|c|c|c|}
\hline I decided to harvest because... & $\begin{array}{l}\text { Strongly } \\
\text { Disagree }\end{array}$ & Disagree & Agree & $\begin{array}{c}\text { Strongly } \\
\text { Agree }\end{array}$ \\
\hline ...my neighbors were logging their timber. & 1 & 2 & 3 & 4 \\
\hline $\begin{array}{l}\text {..I needed income (e.g., house, vacation, medical } \\
\text { expenses) }\end{array}$ & 1 & 2 & 3 & 4 \\
\hline $\begin{array}{l}\text {...I needed to improve conditions of my stand. } \\
\text { (e.g., remove diseased trees, wildlife habitat) }\end{array}$ & 1 & 2 & 3 & 4 \\
\hline $\begin{array}{l}\text { I wanted to improve access to my property. (e.g., } \\
\text { housing site, roads, create pasture) }\end{array}$ & 1 & 2 & 3 & 4 \\
\hline ...other: & 1 & 2 & 3 & 4 \\
\hline
\end{tabular}

11. When you were deciding to sell timber, what were your main concerns?

12. Please read the following statements and mark how strongly you agree or disagree.

\begin{tabular}{|c|c|c|c|c|}
\hline Before I sold timber I... & $\begin{array}{l}\text { Strongly } \\
\text { Disagree }\end{array}$ & Disagree & Agree & $\begin{array}{c}\text { Strongly } \\
\text { Agree }\end{array}$ \\
\hline ...knew about ways to minimize logging erosion. & 1 & 2 & 3 & 4 \\
\hline ... was able to identify invasive plant species. & 1 & 2 & 3 & 4 \\
\hline ... knew that a contract was important. & 1 & 2 & 3 & 4 \\
\hline $\begin{array}{l}\text { had a clear set of goals established for my } \\
\text { property. }\end{array}$ & 1 & 2 & 3 & 4 \\
\hline ...discussed selling timber with my neighbors. & 1 & 2 & 3 & 4 \\
\hline ...discussed selling timber with my family. & 1 & 2 & 3 & 4 \\
\hline $\begin{array}{l}\text {...was aware of my potential liability to logging } \\
\text { and logging related injuries. }\end{array}$ & 1 & 2 & 3 & 4 \\
\hline
\end{tabular}

Part 3. Planning the timber sale

13. Please read the following statements and mark how strongly you agree or disagree.

\begin{tabular}{|c|c|c|c|c|}
\hline $\begin{array}{l}\text { Before the logging began, I felt I was prepared } \\
\text { for... }\end{array}$ & $\begin{array}{l}\text { Strongly } \\
\text { Disagree }\end{array}$ & Disagree & Agree & $\begin{array}{l}\text { Strongly } \\
\text { Agree }\end{array}$ \\
\hline ... how my property would look during the logging. & 1 & 2 & 3 & 4 \\
\hline ... how my property would look after the logging. & 1 & 2 & 3 & 4 \\
\hline ... how much income I was to receive. & 1 & 2 & 3 & 4 \\
\hline ... the harvest. I knew what to expect. & 1 & 2 & 3 & 4 \\
\hline
\end{tabular}


Directions: Please mark answers clearly. For sections with 2 columns below please see the following:

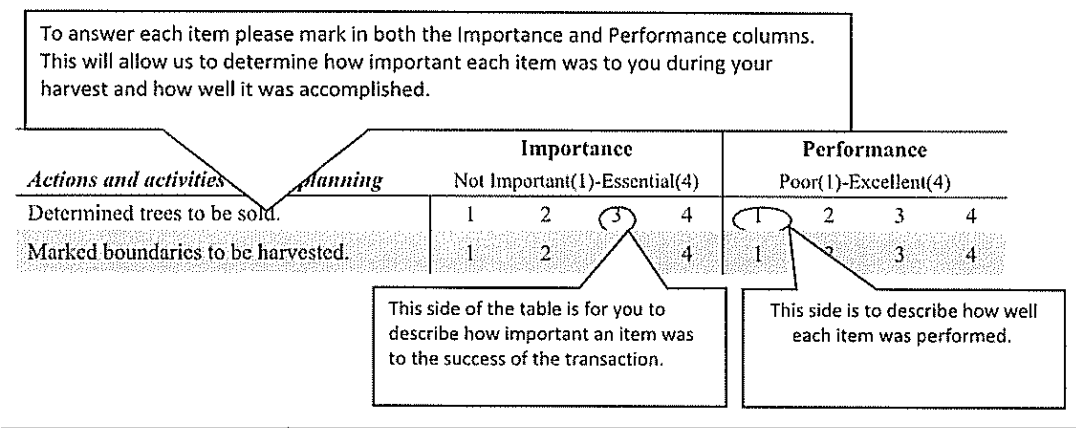

14. Please circle the numbers that best describes how important each individual was to the success of your timber sale and how well they performed during your timber sale. If an individual was not part of the timber sale, please circle "not contacted".

\begin{tabular}{|c|c|c|c|c|c|c|c|c|c|}
\hline \multirow{2}{*}{$\begin{array}{l}\text { People who may have been involved } \\
\text { Private Consulting Forester }\end{array}$} & \multicolumn{4}{|c|}{$\begin{array}{c}\text { Importance } \\
\text { Not Important (1)- } \\
\text { Essential(4) }\end{array}$} & \multicolumn{4}{|c|}{$\begin{array}{l}\text { Performance } \\
\text { Poor }(1) \\
\text { Excellent }(4)\end{array}$} & \multirow[b]{2}{*}{ Not contacted } \\
\hline & 1 & 2 & 3 & 4 & 1 & 2 & 3 & 4 & \\
\hline Company Procurement Forester & 1 & 2 & 3 & 4 & 1 & 2 & 3 & 4 & Not contacted \\
\hline WV DOF (State) Forester & 1 & 2 & 3 & 4 & 1 & 2 & 3 & 4 & Not contacted \\
\hline Logging company & 1 & 2 & 3 & 4 & 1. & 2 & 3 & 4 & Not contacted \\
\hline Other Party: & 1 & 2 & 3 & 4 & 1 & 2 & 3 & 4 & Not contacted \\
\hline
\end{tabular}

15. Please select how important each item was to the success of your timber sale and how well each item was performed during the planning phase.

\begin{tabular}{|c|c|c|c|c|c|c|c|c|}
\hline \multirow{2}{*}{$\begin{array}{l}\text { Actions and activities during planning } \\
\text { Determined trees to be sold. }\end{array}$} & \multicolumn{4}{|c|}{$\begin{array}{c}\text { Importance } \\
\text { Not Important(1)-Essential(4) }\end{array}$} & \multicolumn{4}{|c|}{$\begin{array}{c}\text { Performance } \\
\text { Poor(1)-Excellent(4) }\end{array}$} \\
\hline & 1 & 2 & 3 & 4 & 1 & 2 & 3 & 4 \\
\hline Marked boundaries to be harvested. & 1 & 2 & 3 & 4 & 1 & 2 & 3 & 4 \\
\hline $\begin{array}{l}\text { Marked boundaries of areas off limits to } \\
\text { loggers. }\end{array}$ & 1 & 2 & 3 & 4 & 1 & 2 & 3 & 4 \\
\hline Determined types of equipment to be used. & 1 & 2 & 3 & 4 & 1 & 2 & 3 & 4 \\
\hline $\begin{array}{l}\text { Determined potential layouts for } \\
\text { skid/wood roads. }\end{array}$ & 1 & 2 & 3 & 4 & 1 & 2 & 3 & 4 \\
\hline Determined goals for my property & 1 & 2 & 3 & 4 & 1 & 2 & 3 & 4 \\
\hline Determined how taxes would be paid. & 1 & 2 & 3 & 4 & 1 & 2 & 3 & 4 \\
\hline Discussed Best Management Practices & 1 & 2 & 3 & 4 & 1 & 2 & 3 & 4 \\
\hline Discussed method of payment. & 1 & 2 & 3 & 4 & 1 & 2 & 3 & 4 \\
\hline
\end{tabular}


16. Please select the most correct statement for your timber sale (please check only one). My timber was sold as...

Sealed bid- An inventory of the timber was sent to as many buyers as possible. The company was selected based on the quality of the bid submitted.

Negotiated sale-Sold to a single representative of a mill or logging company.

Paid on shares-The logging company harvested the trees and sold them at the mill. The logging company then gave me a percentage of the money that was received from the mill.

Other:

\section{Part 4. The Logging Operations}

17. How often did you visit the site while logging was occurring?

18. Please select how important each item was to the success of your logging operation. Then please select how well you perceived that each item that was performed during the harvest.

\begin{tabular}{|c|c|c|c|c|c|c|c|c|}
\hline \multirow{2}{*}{$\begin{array}{l}\text { During the timber harvesting, I felt... } \\
\text {... welcome when I visited the site. }\end{array}$} & \multicolumn{4}{|c|}{$\begin{array}{c}\text { Importance } \\
\text { Not Important(1)- } \\
\text { Essential(4) } \\
\end{array}$} & \multicolumn{4}{|c|}{$\begin{array}{c}\text { Performance } \\
\text { Never Occurred(1)- } \\
\text { Always Occurred (4) }\end{array}$} \\
\hline & 1 & 2 & 3 & 4 & 1 & 2 & 3 & 4 \\
\hline ...questions and concerns were answered. & 1 & 2 & 3 & 4 & 1 & 2 & 3 & 4 \\
\hline $\begin{array}{l}\text {...informed of each load that was sent to the } \\
\text { mill. }\end{array}$ & 1 & 2 & 3 & 4 & 1 & 2 & 3 & 4 \\
\hline ...notified of problems during the harvest. & 1 & 2 & 3 & 4 & 1 & 2 & 3 & 4 \\
\hline $\begin{array}{l}\text {...the logger notified me of state forester } \\
\text { visits or findings. }\end{array}$ & 1 & 2 & 3 & 4 & 1 & 2 & 3 & 4 \\
\hline $\begin{array}{l}\text {..notified of changes in pricing of different } \\
\text { species. }\end{array}$ & 1 & 2 & 3 & 4 & 1 & 2 & 3 & 4 \\
\hline
\end{tabular}

19. Please select how important each item was to the success of your logging operation. Then please select how well you perceived that each item that was performed during the harvest.

\begin{tabular}{|c|c|c|c|c|c|c|c|c|}
\hline \multirow{2}{*}{$\begin{array}{l}\text { The logging company.... } \\
\text {...logged only trees that were agreed upon. }\end{array}$} & \multicolumn{4}{|c|}{$\begin{array}{l}\text { Importance } \\
\text { Not Important(1)- } \\
\text { Essential(4) } \\
\end{array}$} & \multicolumn{4}{|c|}{$\begin{array}{c}\text { Performance } \\
\text { Poor(1)-Excellent(4) }\end{array}$} \\
\hline & 1 & 2 & 3 & 4 & 1 & 2 & 3 & 4 \\
\hline ...stayed in agreed upon areas. & 1 & 2 & 3 & 4 & 1 & 2 & 3 & 4 \\
\hline ...only used designated gates and roads. & 1 & 2 & 3 & 4 & 1 & 2 & 3 & 4 \\
\hline ...followed Best Management Practices. & 1 & 2 & 3 & 4 & $: 1$ & 2 & 3 & 4 \\
\hline ...filled in ruts. & 1 & 2 & 3 & 4 & 1 & 2 & 3 & 4 \\
\hline ...seeded and mulched trails and landing. & 1 & 2 & 3 & 4 & 1 & 2 & 3 & 4 \\
\hline ...left residual trees in good condition. & 1 & 2 & 3 & 4 & 1 & 2 & 3 & 4 \\
\hline ...smoothed trails and landing. & 1 & 2 & 3 & 4 & 1 & 2 & 3 & 4 \\
\hline ...followed the contract. & 1 & 2 & 3 & 4 & 1 & 2 & 3 & 4 \\
\hline
\end{tabular}


20. Who or what was your main source of information during the timber transaction? Do you feel satisfied with accuracy of the information received?

21. Please read the following statements and mark how strongly you agree or disagree

\begin{tabular}{l|cccc}
\hline In general, how satisfied were you with the... & $\begin{array}{c}\text { Very } \\
\text { Dissatisfied }\end{array}$ & Dissatisfied & Satisfied & $\begin{array}{c}\text { Very } \\
\text { Satisfied }\end{array}$ \\
\hline ...amount of revenue received? & 1 & 2 & 3 & 4 \\
$\begin{array}{l}\text {... entire timber sale? } \\
\text {..your contract? }\end{array}$ & 1 & 2 & 3 & 4 \\
$\ldots$ completion of your property goals? & 1 & 2 & 3 & 4 \\
...condition of your property after the harvest? & 1 & 2 & 3 & 4 \\
$\ldots$...information related to harvesting practices? & 1 & 2 & 3 & 4 \\
\hline
\end{tabular}

22. Were there any additional activities after the harvest?

No $\square$ Yes, what was done? Were you satisfied? Why or why not.

23. What were the best things about your most recent timber sale?

24. What were the worst things about your most recent timber sale?

25. Do you plan to harvest again?

Yes $\square$ No. If No, why not?

26. If you could do it again, how would you do it differently to make it more successful? 
27. During the entire timber sale, from the first idea to sell until its completion, were you ever concerned about the financial aspects? If so, when and why were you concerned? If not, why not?

Part 6. Demographics-

28. What is your gender?

Male $\square$ Female

29. What is your age?

\begin{tabular}{|c|c|c|c|}
\hline $18-24$ & $25-34$ & $35-44$ & $45-54$ \\
\hline $65-74$ & $75-84$ & 84 or 8 & \\
\hline
\end{tabular}

30. What is your annual gross income

\begin{tabular}{|c|c|c|}
\hline$\$ 15,000-\$ 24,999$ & $\$ 25,000-\$ 49,999$ & $\$ 50,000-\$ 74,999$ \\
\hline$\$ 75,000-\$ 99,999$ & $\$ 100,000-\$ 199,999$ & $\$ 200,000$ \\
\hline
\end{tabular}

31. What is the highest level of education you have completed?

\begin{tabular}{|c|c|c|}
\hline Some High School & High School & Associate's Degree \\
\hline Bachelor's Degree & Master's Degree & Ph.D. or higher \\
\hline Trade School & Prefer not to say & \\
\hline
\end{tabular}

\section{Thank you for participating in this survey!}

Please return the completed questionnaire in the postage-paid envelope. 
